\title{
Pathology of different tau protein species in neurodegenerative diseases: Alzheimer's disease, corticobasal degeneration, and progressive supranuclear palsy
}

\author{
Mohammad Majidi ${ }^{1}$, Aref Rajabi ${ }^{2}, \underline{\text { Shamseddin Ahmadi }}$
}

1.M.Sc. Student, Department of Biological Science, Faculty of Science, University of Kurdistan, Sanandaj, Iran. ORCID ID: 0000-0002-0849-3319

2.M.D. \& Ph.D. in Neurology, Department of Neurology, Kurdistan University of Medical Sciences, Sanandaj, Iran. ORCID ID: 0000-0001-6909-1420

3.Associate Professor, Department of Biological Science, Faculty of Science, University of Kurdistan, P.O. Box 416, Sanandaj, Iran., (Corresponding author), Tel: +98-87-33660075, E-mail: sh.ahmadi@uok.ac.ir. ORCID ID: 0000-00030300-3226

\begin{abstract}
Background and Aim: Tau protein is a microtubule-associated protein that plays a critical role in microtubule dynamics and maintaining the structure of neurons. Tau isoforms with three or four repeated domains at the c-terminal are known as $3 \mathrm{R}$ or $4 \mathrm{R}$ isoforms, respectively. Hyperphosphorylation of tau impairs its original structure and function and causes accumulation of tau as tangled filaments known as neurofibrillary tangles. The aim of this study was to review the structure and physiological function of tau and also the role of accumulation and deposition of tau in induction of neurodegenerative diseases.
\end{abstract}

Materials and Methods: Relevant reports about the deposition of tau protein in neurodegenerative diseases were summarized from scientific articles.

Results: Deposition of the filamentous tau in neurons and glial cells causes cell damage and induces neurodegenerative diseases such as Alzheimer's disease (AD), cortico-basal degeneration (CBD), and progressive supranuclear palsy (PSP). The type of tau isoform and its site of deposition in neurons, astrocytes, and oligodendrocytes are different in these diseases, which can be a useful clue for precise diagnosis of the above mentioned diseases. In $\mathrm{AD}$ both $3 \mathrm{R}$ and $4 \mathrm{R}$ isoforms are deposited only in neurons, but in PSP and CBD only $4 \mathrm{R}$ isoform is deposited in neurons and glial cells.

Conclusion: Knowledge of the physiological functions and pathogenesis of tau and decreasing the hyperphosphorylated form of tau by inhibition of protein kinases, can lead to development of a diagnostic and therapeutic strategy for neurodegenerative diseases induced by tau protein.

Keywords: Tau protein, Protein kinases, Neurofibrillary tangles, Tauopathies Received: Oct 7, 2020

Accepted: Feb 2, 2021

How to cite the article: Mohammad Majidi, Aref Rajabi, Shamseddin Ahmadi. Pathology of different tau protein species in neurodegenerative diseases: Alzheimer's disease, corticobasal degeneration, and progressive supranuclear palsy.q́úSJKU 2021;26(3):129-150.

Copyright (C) 2018 the Author (s). Published by Kurdistan University of Medical Sciences. This is an open access article distributed under the terms of the Creative Commons Attribution-Non Commercial License 4.0 (CCBYNC), where it is permissible to download, share, remix, transform, and buildup the work provided it is properly cited. The work cannot be used commercially without permission from the journal 


\section{بيمارىزايى تونههاى مختلف تاو بروتئين در بيمارىهاى تحليل برنده عصبى:

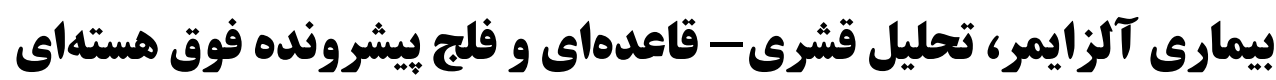

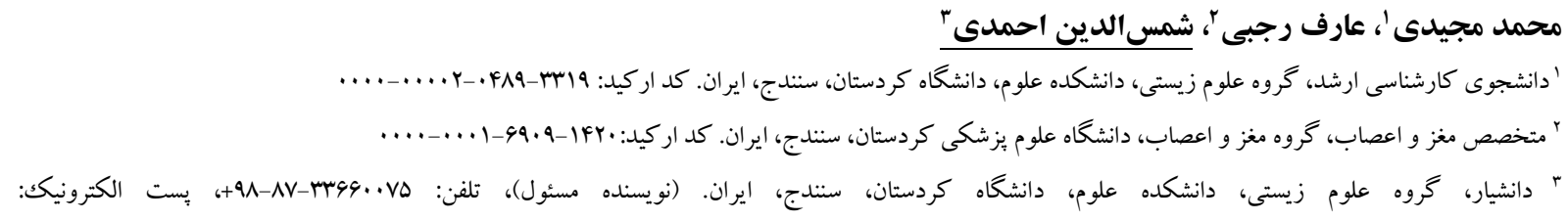

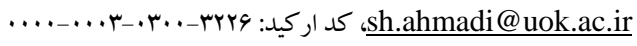

جـكيده

زمينه و هدف: تاو يروتئين يك بروتئين مرتبط با ميكروتوبول است كه نقش ويزهاى در يويايى ميكروتوبول و حفظ ساختار

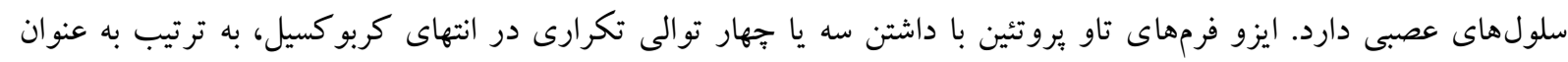

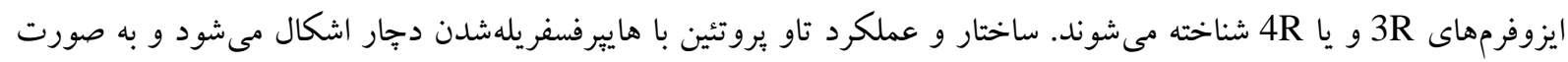

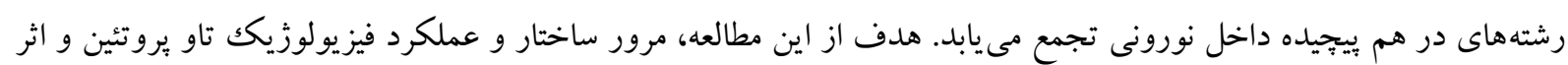
تجمع تاو يروتئين و رسوب آن در القاى بيمارىهاى تحليل برنده اعصاب است. مواد و روشها: گزارشهاى مرتبط با رسوب تاو يروتئين در بيمارىهاى تحليل برنده عصبى از مقالههاى علمى جمعبندى كرديد. يافتها: رسوب فرمهاى رشتهاى تاو بروتئين در سلولهاى عصبى و كليال موجب آسيب سلولى و بروز بيمارىهاى تحليل برنده

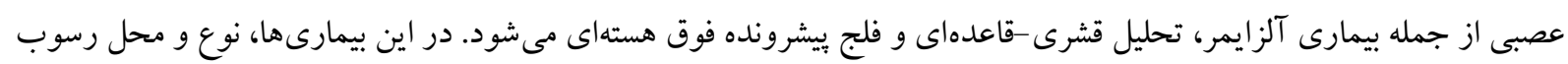

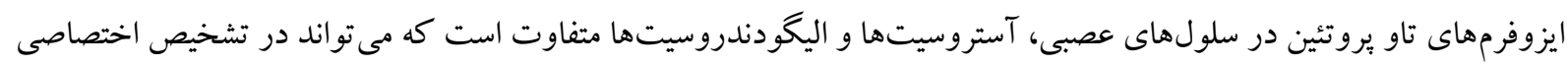
بيمارى كاربرد داشته باشد. در بيمارى آلزايمر، رسوب حاوى دو ايزوفرم 3R و 4R تاو بروتئين فقط در سلول عصبى ديده مى شودي؛ اما در بيمارىهاى تحليل قشرى-قاعدهاى و فلج بيشرونده فوق هسته اى، رسوب هاى تاو بروتئين فقط حاوى ايزوفرم 4R هستند و در سلولهاى عصبى و كليال ديده مىشوند. نتيجه كيرى: با شناخت بيشتر عملكر دهاى فيزيولوزيكك و بيمارىزايى تاو بروتئين و كنترل ميزان تاو بروتئين هاييرفسفريله با مهار يروتئين كينازها، مىتوان به يكك راهكار تشخيصى و درمانى ههم در بيمارىهاى تحليل برنده عصبى ناشى از تاو يروتئين

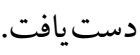
كلمات كليدى: تاو بروتئين، يروتئين كينازها، رشتهاى درهم بيجيده داخل نورونى، بيمارىزايى تاو بروتئين

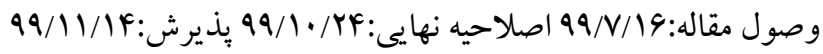


داشته باشد (F). تاو بروتئين ممكن است كه به عنوان يكك

مولكول بيامرسان در تنظيم بيان زن نيز نقش داشته باشد (ه). عملكرد پِس سينايسى تاو يروتئين مشخص نشده است؛ اما ممكن است در انعطاف پِذيرى سينإيى Synaptic) plasticity) يروتئين در مسير اتوفازى، از طريق جلو گيرى از ادغام

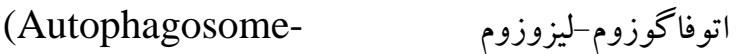
سبب سركوب و كاهش شديد ميزان Lysosome) اتوفازى در سلولها مى كردد (V). تاو يروتئين به طور طبيعى داراى نواحى فسفريلاسيون زيادى است كه تحت تأثير كينازهاى مختلف قرار مى گيرند. ميزان طبيعى فسفريله شدن تاو يروتئين سبب يويايى آن مى شود و در عملكرد طبيعى آن اهميت دارد؛ اما فسفريلاسيون بيش از حد تاو بروتئين در سلولهاى عصبى و كليال با ايجاد الدي رسوبات رشتهاى داخل سلولى، سبب ايجاد طيف وسيعى از

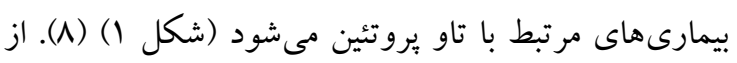
جمله بيمارىهاى مرتبط با تاو تروتئين مىتوان بيمارى آلزايمر (Alzheimer's Disease, AD)، تحليل قشرى قاعدهاى (Cortico-Basal Degeneration, CBD)

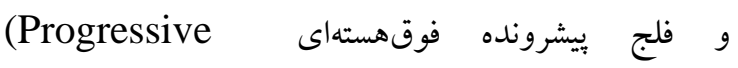
Supranuclear Palsy, PSP) مطالعه اين است كه ضمن ارائه اطلاعاتى در مورد زن كد

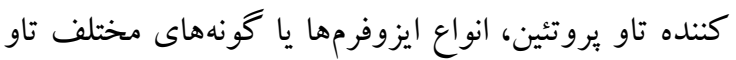
يروتئين مرتبط با ميكروتوبول و نيز انواع موجود در تجمعات رسوبى را معرفى نماييم. در ادامه، عوامل تحريكك كننده و عوامل مولكولى مؤثر در هايير فسفريله شدن تاو بروتئين را بررسى مى كنيم. در نهايت به بررسى و مرور آخرين يافتهاى مرتبط با رسوب تاو يروتئين در انواع مختلف سلولهاى دستكاه عصبى به عنوان عوامل اصلى در بيمارىزايى و نيز تشخيص دقيق هر يكك از بيمارىهاى
خانوادهى يروتئينهاى تاو (Tau) مختص دستكاه عصبى هستند كه به عنوان يروتئين هاى مرتبط با ميكروتوبول در (Microtubule-Associated Protein, MAP) فر آيند تجمع و پيايدارى ميكروتوبولها نقش دارند (1). تاو بروتئين (Tau protein) عضوى از اين خانوادهى است كه به طور عمده در ناحيهى آكسونى سلولهاى عصبى و به مقدار كمتر در دندريتها و جسم سلولى وجود دارد (Y). تاو يروتئين در دستخاه عصبى مركزى داراى شش ايزوفرم و در دستگاه عصبى محيطى داراى يكك ايزوفرم با دو حالت متفاوت است. اين بروتئين ror تا أFF آمينواسيد طول دارد و از يك زن منفرد با علامت اختصارى MAPT (Microtubule-Associated Protein Tau, مشتق مى شود. در مغز بزر گسالان اين يروتئين از MAPT) جهار تا شش يلىييتيد با وزن تقريبى •ه تا 91 كيلودالتون تشكيل شده است، در حالى كه در مغز جنين وزنى معادل

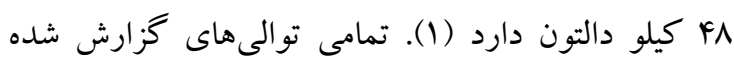
براى تاو يروتئين داراى يكك انتهاى كربو كسيل هستند كه نيمى از اين توالى در حدود اس تا بr آمينواسيد طول داردو داراى يكك مشخصهى آمينواسيدى pro-gly-gly-gly به عنوان نشانگر است (r). تاو يروتئين به طور عمده در تنظيم پايدارى ميكروتوبول و آنس همجنين انتقال آكسونى محمولههاى مولكولى بين جسم سلولى و بِايانهاى سينايسى دور نقش دارد. تاو يروتئين

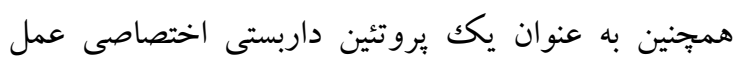

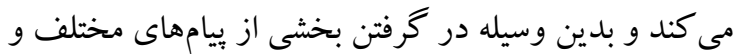
هدايت آبشارى ويامرسانى نقش دارد. علاوه بر نقش تاو يروتئين در دندريت و آكسون، عملكرد آن در هسته نيز گزارش شده است، به نحوى كه تاو يروتئين مى تواند در تنظيم فعاليتهاى رونويسى، حفظ يكّارجّكى و تماميت فيزيولوزيكى DNA و RNA در شرايط استرس نقش ونس 
ميكروتوبول است، با توجه به حضور تعداد توالىهاى

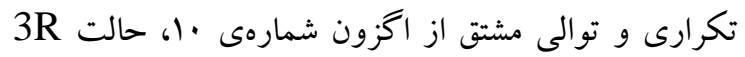

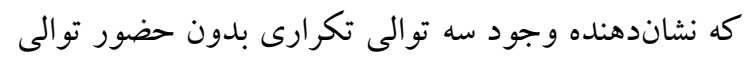
شماره •ا و حالت 4R كه نشاندهنده وجود جهار توالى 1. شامل سه توالى تكرارى به همراه توالى اكزون شماره است، وجود خواهد داشت. در اين ايزوفرمها اكزون شماره

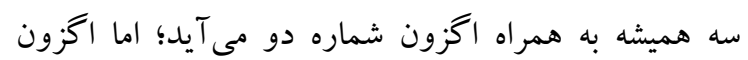

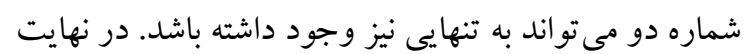

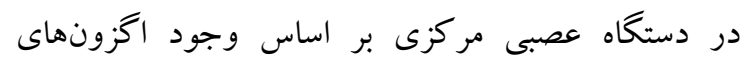
توضيح داده شده در انتهاى آمينى و توالىهاى تكرارى در بر بر انتهاى كربو كسيل تاو بروتئين، شش ايزوفرم وجود دارد كه از كوجکك به بزرگك بر اساس طول توالى يروتئين به نامهاى تروني 2N4R و 1N4R ،0N4R 2N3R، 1N3R،0N3R

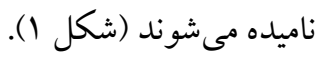

در دستكاه عصبى محيطى (Peripheral Nervous) يكك ايزوفرم بزرگك از تاو بروتئين بيان System, PNS)

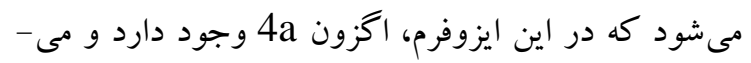
تواند به همراه اكزون 9 نيز حضور داشته باشد كه در نهايت مىتواند دو حالت را به نامهاى (+)/6a(+) كه داراى

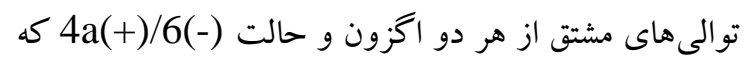
فقط داراى توالى مشتق از اخزون 4a است، ايجاد نمايد

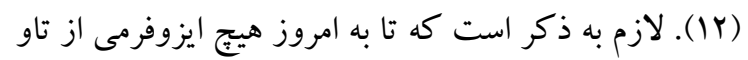

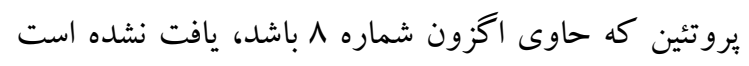

آلزايمر، تحليل قشرى قاعدهاى و فلج ييشرونده فوق هستهاى مى بيردازيم.

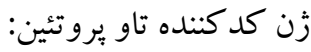
تاو يروتئين يكك يروتئين مرتبط با ميكروتوبول است كه به عنوان محرك يليمريزه شدن توبولين و در نقل و انتقال توبولين بين حالتهاى كوتاه شدن و طويل شدن ميكروتوبول نقش دارد و به اين ترتيب باعث ايجاد يك حالت پايدار و يويا در ميكروتوبول مىشود (9). زن كد كننده تاو يروتئين به اختصار MAPT ناميده مىشود. اين زن بر روى بازوى طويل كروموزوم شمارهى IV و در موقعيت 17q21.31 قرار دارد (•(1). در مطالعهاى كه بر روى جمعيتهاى ارويايى انجام شده است، از اين زن دو

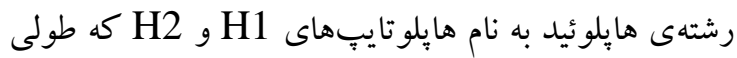
معادل . .9 كيلو باز دارند، جدا شده است. زن تاو بهطور كلى داراى 19 اخزون است كه كدونهاى آغازين و پايانى به ترتيب در اخزونهاى يك و سا قرار دارند. در دستگاه عصبى مر كزى (Central Nervous System, CNS) اخزونهاى شمارهى r، r و ، •ا تحت تأثير بيرايش ثانويه قرار مى گيرند (1) و با توجه به حضور اخزونهاى ك، ساو .1

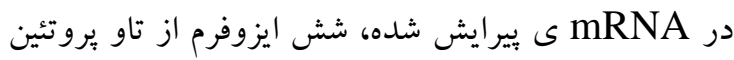
تشكيل مىشود (9، 11). بسته به عدم وجود و يا دارا بودن توالىهاى مشتق از اخزونهاى شماره دو و سه در انتهاى آمينى، به ترتيب سه حالت 0N، $1 \mathrm{~N}$ مختلف تاو بروتئين ديده مىشود. در انتهاى كربو كسيل تاو يروتئين نيز كه ناحيه اتصال توالىهاى تكرارى به 


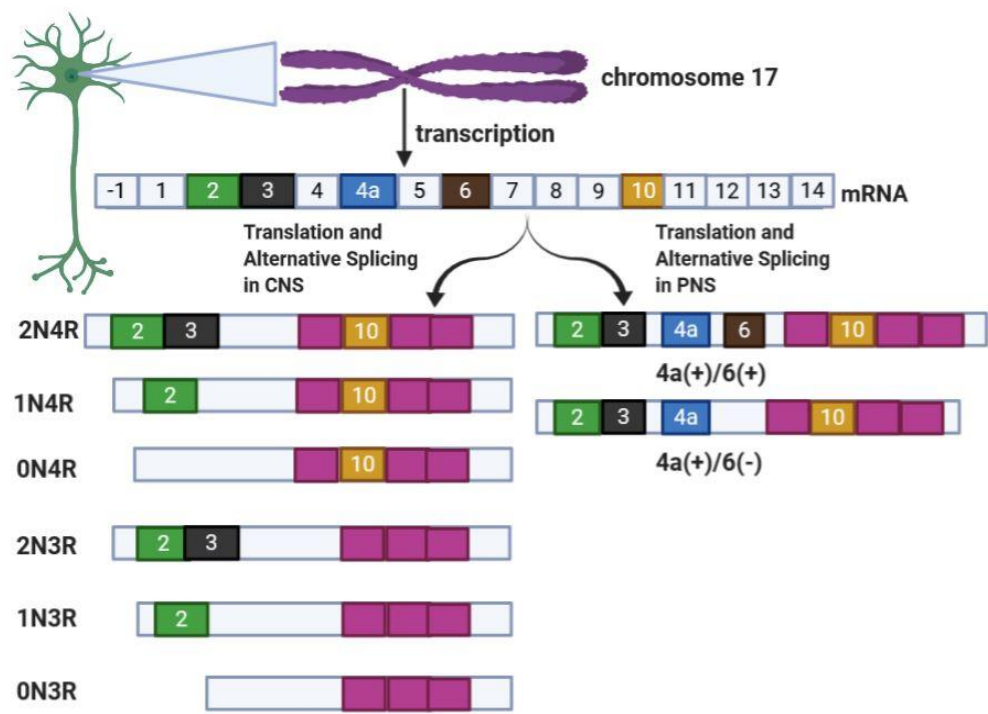

شكل 1. ايزوفر مهاى تاو يروتئين در دستكاه عصبى مر كزى و محيطى. زُن MATP كه كدكندهى تاو يروتئين است، بر روى كروموزوم شمارهى VI لدر جايكاه

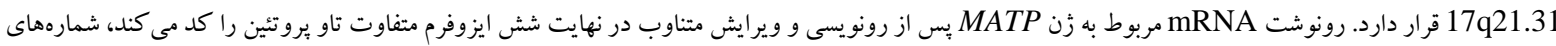

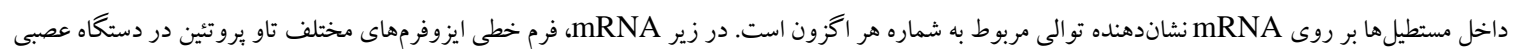

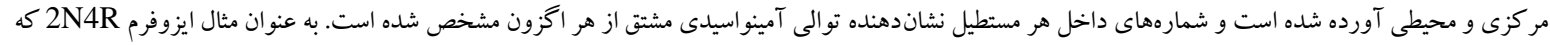

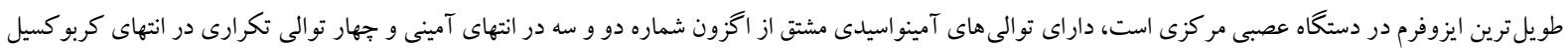

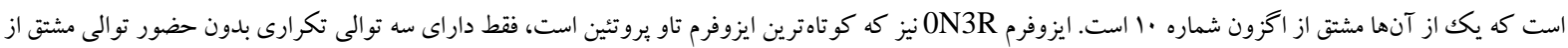

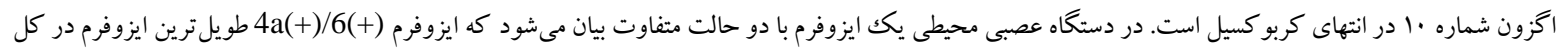
دستكاه عصبى است (rir). Peripheral Nervous System, PNS Central Nervous System, CNS.

يروتئين در بين رشتههاى ميكروتوبولها قرار مى گيرند و به صورت جانبى به آنها متصل مىشوند و در نتيجه باعث ايجاد يلهايى بين رشتههاى ميكروتوبولهاى مجاور مى شوند (19). اتصالات تاو يروتئين به ميكروتوبولها توسط فسفريله شدن تنظيم مىشود و يك اتصال با بويايى بالا است و داراى استحكام زياد اما موقت است، به طورى كه هر اتصال · f هزارم ثانيه طول مى كشد و سيس اتصال قطع مىشود، سبس دوباره متصل مىشود و اين حالت بيوسته

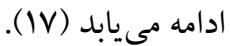
هايبرفسفوريلاسيون تاو بروتئين: افزايش فسفريله شدن يا هايِيرفسوريلاسيون تاو يروتئين، باعث كاهش تمايل اتصال تاو يروتئين به ميكروتوبول مى شود كه به نوبه خود بر روى يايدارى شبكهى ميكروتوبولى مؤثر است و ممكن است باعث اختلال در نقل و انتقال
فسفريله شدن تاو بروتئين: عملكردهاى سلولى تاو بروتئين و ميانكنش هاى آن با يك (Post- سرى از يروتئينها موجب تغييرات پس از ترجمه translational modifications) مىشود كه اين تغييرات شامل استيله شدن، كليكوزيله شدن، متيله شدن، نيتراته شدن، كوتاه شدن، يوبى كوئيتينه شدن و فسفريله شدن است (F) f (F). فسوريله شدن تاو بروتئين يكى از عمده ترين تغييرات پِ از ترجمه است كه با تنظيم دقيق عملكرد فيزيولوزيك تاو تيروتئين مرتبط است. در حالت طبيعى، رشتهاى ميكروتوبول توسط تاو يروتئين پايدار و تثيت مى شوند. محدودههاى اتصالى تاو يروتئين از سطح داخلى به سطح خارجى ميكروتوبولها راه دارد و به آن متصل است و انتهاى آمينى اين محدودهها از ميكروتوبول دور است (ها)؛ بنابراين مولكولهاى تاو

هبلم علمى دانشكاه علوه يِشكى كردستان / دوره بيست و شش / درداد و شهريور م.ع|| 
ايجاد فرم هايبرفسفريله تاو يروتئين ايجاد كنند.در صورت فسفريله شدن بيش از حد تاو يروتئين، امكان خودتجمعى و تشكيل جفت رشتههاى مارييج و (Self-Assemble) تودههاى درهم تنيده داخل نورونى Neurofibrillary از رشته هاى تاو يروتئين وجود دارد كه هر كدام از اين موارد مىتواند در بيمارىزايى تاو بروتئين نقش اساسى داشته باشند (19).
آكسونى شود (1) (شكل -YY)؛ اما از عوامل مؤثر در ايجاد تاو يروتئين هايِرفسفريله مىتوان آزادسازى بيش از حد مولكولهاى التهابى، آسيبهاى عصبى و اختلال در عملكرد فيزيولوزيكى سلولهاى عصبى، آسيبهاى زنتيكى به DNA و DNA، عوامل ارثى و عوامل محيطى مانند جاقى، استرس و فشارىهاى عصبى، تغذيه نامناسب و عدم فعاليتهاى فيزيكى را نام برد كه مىتوانند زمينه را براى
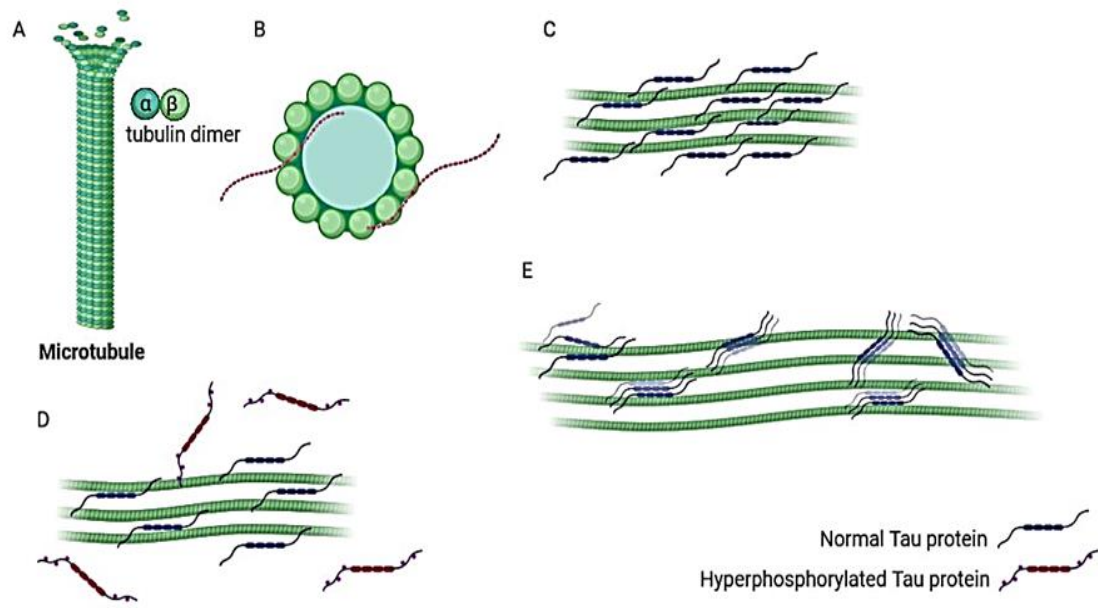

شكل ז. نحوه اتصال تاو يروتئين به ميكروتوبول. A: ميكروتوبولهاى فعال و يويا از اتصال دايمرهاى توبولين آلفا و بتا به انتهاى ميكروتوبول ايجاد مىشود. اتصال تاو

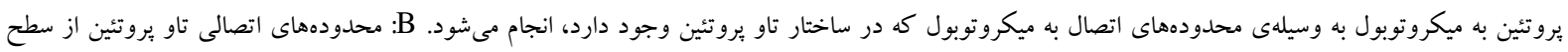

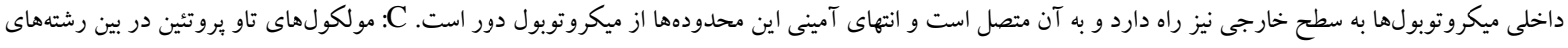

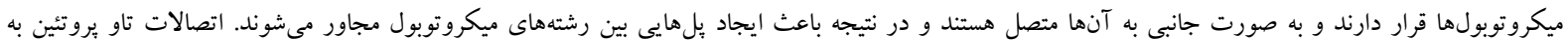

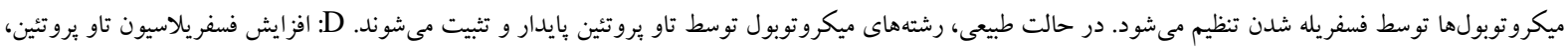

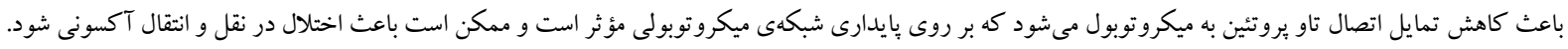

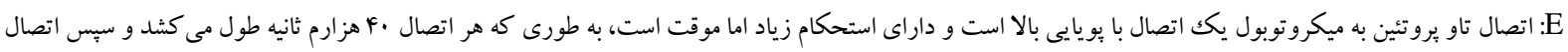

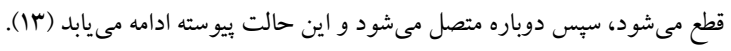

فسفريلاسيون است كه بيشتر اين مكانها بر روى ناحيهى (Microtubule اتصالى تاو وبروتئين به ميكروتوبول binding region) يرولين است (·r (Y) إ). از نواحى با قابليت فسفريله شدن، Fo مورد مربوط به آمينو اسيد سرين، ها مورد مربوط به آمينواسيد ترئونين و بنج مورد هم مربوط به تيروزين است
جايگاههاى فسفريلاسيون بر روى تاو بروتئين: با استفاده از طيف سنجى جرمى و يا با استفاده از آنتى بادىهاى اختصاصى فسفريله شده، تعداد زيادى از نواحى با قابليت فسفريله شدن در تاو يروتئين يافت شده است، البته برخى از اين نواحى بسته به شرايط ياتولوزيكى فسفريله

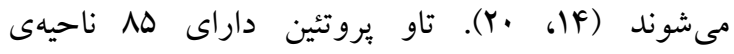




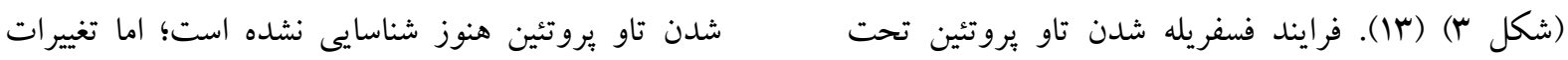
ساختارى بعد از آن سبب القاى جدا شدن تاو بروتئين از ماز كنترل سرين/ترئونين كينازها يا تيروزين كينازهاى مختلفى

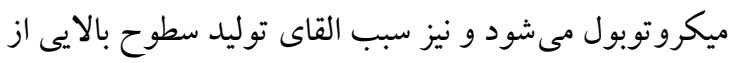
از جمله Glycogen Synthase Kinase GSK3 تاو بروتئين محلول مىشود كه همهى اينها قبل از تشكيل (Cyclin-Dependent Kinase 5) CDK5, 3 3 )

رشتهاى درهم تنيده داخل نورونى اتفاق مى افتد (YF). تنظيم مىشود (YY). مراحل فسفريله شدن تاو يروتئين در در ساختار تاو يروتئين، IV مورد از مكانهاى داراى آمينواسيد سرين يا ترئونين وجود دارد كه در توالى لى بيمارى آلزايمر به صورت آبشارى و سلسله مراتبى اتفاق مى افتد و برخى از جايگاهها زودتر فسفريله مىشوند. ساختارى يروتئين قبل از اين VI جايگاه، آمينواسيد برولين وجود دارد. در نتيجه وجود اين آمينواسيد مانع از اتصال بسيارى از كينازها و فسفاتازها به اين نواحى مى شود و فقط كينازها و فسفاتازهايى كه توانيى اتصال به برولين را داشته ونه باشند، مى تواند عمل فسفريلاسيون و دفسفريلاسيون را در اين IV جايگاه انجام دهند (YO). برخى از اين كينازها شامل GSK-3 ، CDK

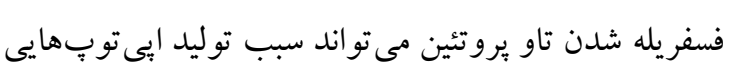
شود كه اين ايىتوبها توسط سلولهاى ايمنى بدن

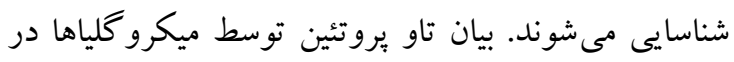

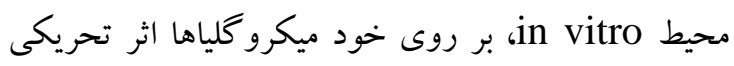
داشته و ساختن دوبارهى تاو يروتئين هاييرفسفريله را افزايش مى دهد و در واقع يكك حلقهى فيدبكك مثبت ايجاد مى كند

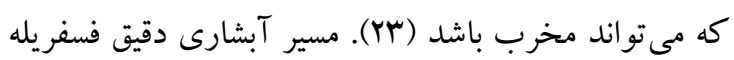

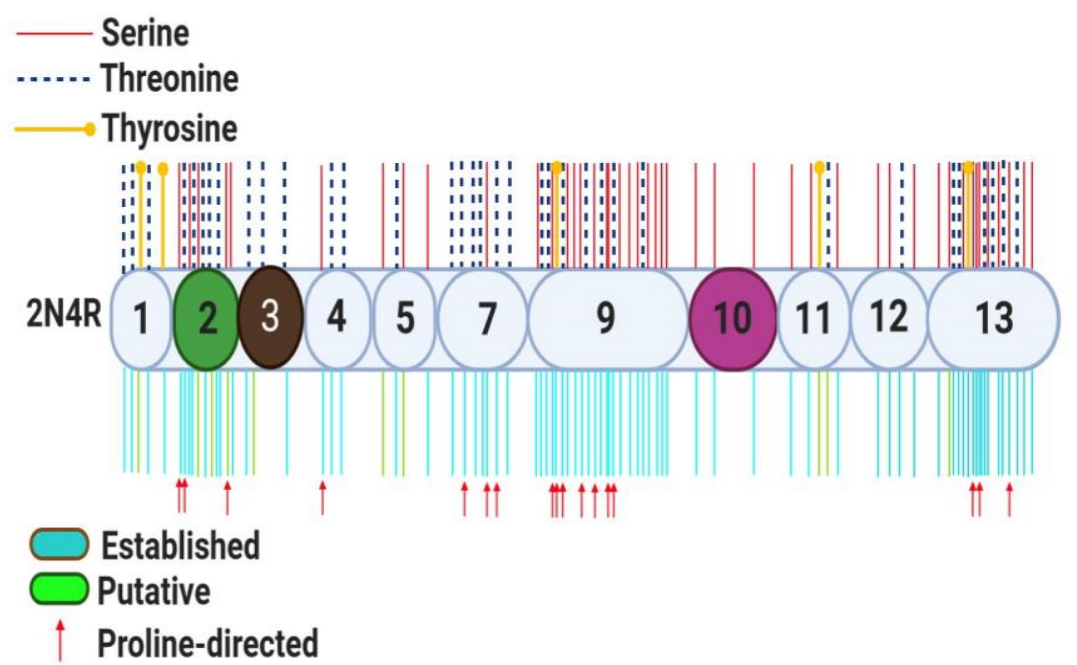

شكل r. جايكاههاى فسفريلاسيون بر روى تاو بروتئين. در قسمت بالاى شكل، جايگاههاى فسفريلاسيون بر روى سه آمينواسيد سرين، ترئونين و تيروزين در ايزوفرم

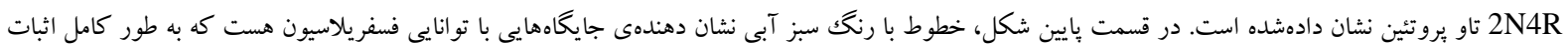

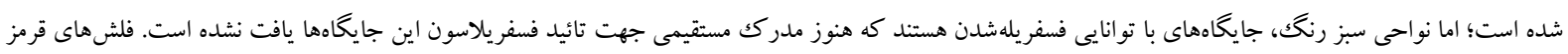
رنغك نشان دهندهى جايكاههاى فسفريلاسيونى است كه فقط كينازهاى خاصى توانايى فسفريلاسيون اين مناطق را دارند (rار)

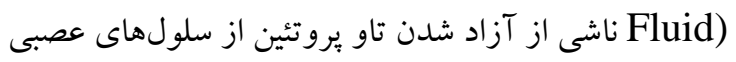
ترشح تاو بروتئين: آسيب ديده است (YV)؛ اما امروزه مشاهده شده است كه سال ها اعتقاد بر اين بود كه در افراد مبتلا به بيمارى آلزايمر، توليد تاو يروتئين يكك روند فعال است (Y^) و شواهد افزايش توليد ميزان مايع مغزى نخاعى Cerebrospinal) 
خارج سلولى مىتواند باعث فعال شدن سيستم ايمنى بدن و آغاز يكك ياسخ ايمنى مبتنى بر آنتىزن شود. در افراد سالم اما مستعد بيمارى آلزايمر، آنتىبادىهاى ضد تاو يروتئين

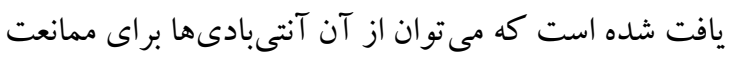
از تشكيل تجمعات تاو بروتئين در محيط in vitro استفاده كرد كه اين كار از طريق گيرندهى سيتوزولى براى آنتىبادى به نام Tripartite motif- TRIM21) containing protein 21) هدف از تحقيقات اخير در اين زمينه، دستيابى به ايمونوترايى موفق تاو يروتئين و كند كردن يِيشرفت بيمارى ناشى از تجمع آن است. لازم به ذكر است كه در اين رابطه، شناسايى ايىتوبهاى ضد تاو و تعاملات موجود بين تاو يروتئين و سيستم ايمنى بدن ضرورى است (rq).

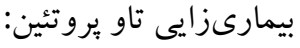
فسفريله شدن تاو يروتئين سبب يويايى آن مىشود؛ اما هاييرفسفريلهدن يا فسفريله شدن بيش از حد تاو يروتئين سبب خودتجمعى در تاو يروتئين و تبديل آن به فرمهاى

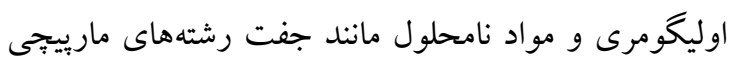
و وشتههاى در (Paired Helical Filament, PHF) هم بييجيده داخل نورونى مى گردد (شكل \&) كه عامل بيمارىزايى تاو يروتئين و ايجاد درجات مختلفى از آسيب عصبى هستند (^). در حالت عادى در مغز يكك فرد سالم، يكك مولكول تاو يروتئين داراى سه مول فسفات است

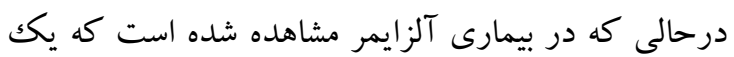
مولكول تاو يروتئين داراى هشت مول فسفات است (F). در حالت بيشرفته بيمارى آلزايمر، بر روى تاو بروتئين حدود ها بنيان آمينواسيد فسفريله شده يافت شده است كه نشاندهنده ارتباط ميزان فسفوريلاسيون تاو يروتئين با بيمارىزايى آن در بيمارىهاى تحليل برنده عصبى است
آزمايشكاهى حاكى از حضور تاو بروتئين در مايع مغزى نخاعى حتّى در موشهاى فاقد آسيب عصبى است. تاو

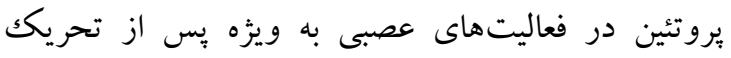

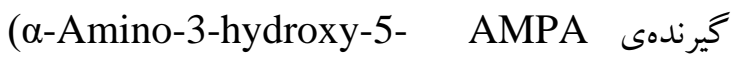
methyl-4-isoxazolepropionic acid, AMPA) كه يك زير گروه از گيرندهاى گلوتامات است، داراى

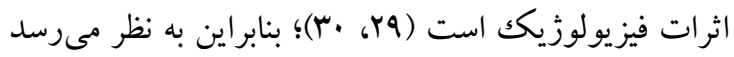
كه ترشح تاو يروتئين در سيستم عصبى براى انجام

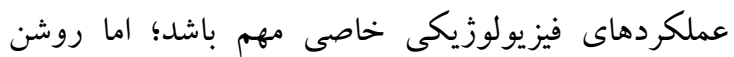
شدن دقيق اين موضوع نياز به مطالعه بيشتر دارد. تاو بروتئين از طريق غشاى بِلاسمايى و به طور مستقيم قبل از تشكيل تجمعات رشتهاى نيز از سلولهاى عصبى آزاد شده و در بين سلولها و نواحى مغزى جابجا مىشود. اين بروتئين به كمكك واسطههاى سلولى مانند فسفاتيديل اينوزيتول و يروتئو كليكانهاى سولفاته ترشح مىشود و فسفريله شدن تاو موجب افزايش ترشح آن از سلولها مىشود (rال).

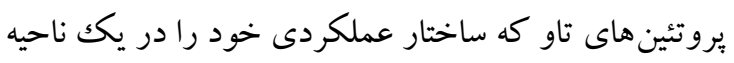
از مغز از دست دادهاند، ابتدا در آن قسمت آسيب ديده از مغز و به صورت سلول به سلول بخش مىشوند و در نتيجه موجب يخش شدن اثرات بيمارىزايى تاو يروتئين در آن

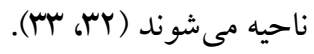
قطع شدگى و كو تاه شدن تاو بروتئين در ناحيهى آمينواسيد آسبارتيكك اسيد و نيز هايبرفسفريله شدن سبب ترشح بيشتر آن مىشود (TF). به عنوان مثال، در مراحل نهايى بيمارى

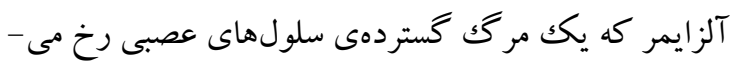
دهد، بروتئين تاو تا حد آمينواسيد ترئونين ال كو تاه مىشود (ه)). در مايع مغزى نخاعى بيماران مبتلا به آلزايمر،

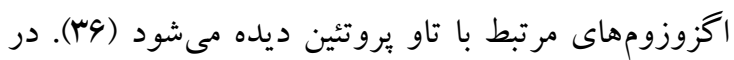

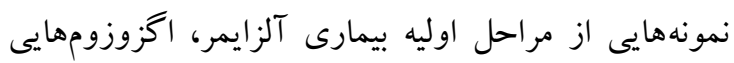
يافت شده است كه حاوى تاو يُروتئين PTH-181؛ به صورت اوليكومرى بوده است (rV). وجود تاو يروتئين 
مى شود و عملكرد سينايسى را تغيير داده و سبب خارج شدن سينايس ها از فعاليت معمول خود مىشود (FV)؛ بنابراين مىتوان نتيجه گيرى نمود كه فرمهاى غيرطبيعى تاو بروتئين با آسيب به سلولهاى عصبى و اختلال در فعاليت سلولهاى ايمنى مغز موجب القاى بيمارىهاى تحليل برنده عصبى مى شوند.

توزيع پِسينايسى تاو بروتئين كه در افراد مبتلا به بيمارى آلزايمر مشاهده شده است، مىتواند عامل سميّت و آسيب به سلول عصبى باشد. در محيط in vivo مشاهده شده است كه تاو بروتئينهاى دندريتى از طريق گيرندهاى (N-Methyl-D-Aspartate, كلو تامات NMDA دار NMDA) هستند (Amyloid $\beta$ ) ليييد رفت (Lipid Raft) در غشاى يلاسمايى، سبب ورود كلسيم به داخل سلول مى شود و افزايش غلظت كلسيم سبب فعال شدن كينازهاى پياييندست دخيل در فسفريلاسيون تاو يروتئين مى گردد (Fq). به عنوان مثال، كلسيم باعث فعال (Adenosine

AMPK شدن monophosphate-activated protein kinase, مى شود كه به نوبه خود سبب فسفريله شدن تاو "يروتئين موجود در دندريت مى گردد. در اين حالت، هايِرفسفريله شدن باعث جدا شدن تاو پيروتئين از ميكروتوبول و همجينين سبب اتصال بيشتر اين بروتئين به كيناز fyn مى شود و در نهايت سبب حركت تاو بروتئين به همراه fyn به سمت خار دندريتى و ناحيهى سينايسى مى گردد كه ممكن است موجب تخريب سينايسى گردد
فعاليت غير عادى كينازها بر روى مونومرهاى تاو يروتئين موجود در ميكروتوبولها، سبب هايبرفسفريلهشن اين يروتئينها مى شود (FY). در تائيد نقش فعاليت زياد كينازها در هايبرفسفوريلاسيون تاو بروتئين، برخى شواهد حاكى از كاهش ميزان تاو يروتئين بيمارىزا در زمان استفاده از كيناز

مهار كنندههاى

(Rho-Associated coiled coil protein ROCK است. در زمان استفاده از kinase, ROCK) مهاركنندهاى اين كيناز، فعاليت يروتئازوم نيز افزايش مىيابد و ميزان اتوفازى در سلولها زياد مىشود كه اين عوامل نيز به كاهش ميزان تاو يروتئين بيمارىزا كمك

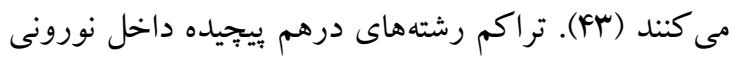
متشكل از تاو بروتئين ارتباط مستقيمى با اختلالات شناختى در بيمارى آلزايمر دارد (FF). همجنين در مطالعاتى كه با استفاده از رديابهاى انتخابى تاو :بروتئين در تكنيك تومو گرافى با انتشار بوزيترون Positron Emission) Tomography, PET) مثبت بين تاو بروتئين تجمع يافته و كاهش عملكردهاى شناختى گزارش شده است كه نشان دهندهى سميّت و بيمارىزايى تاو بروتئين در حالت هايبرفسفريله و نامحلول است (FD). علاوه بر اين، جفت رشتههاى مارييجى تاو يروتئين كه از مغز مبتلايان به بيمارى آلزايمر جدا شده است، با زيرواحد 20S برو تئازوم ميانكنش مىدهند و آن را مهار مى كنند. كاهش فعاليت بروتئازوم و متوقف شدن آن موجب تجمعات غيرطبيعى بروتئينها و سبب ايجاد آبشارى از اتفاقاتى مىشود كه نهايتاً به مرگك سلولهاى عصبى ختم مىشوند (4)). تجمع تاو بروتئين بيمارىزا در داخل نورونها سبب بر هم خوردن فعاليت ميكرو گلياها نيز 


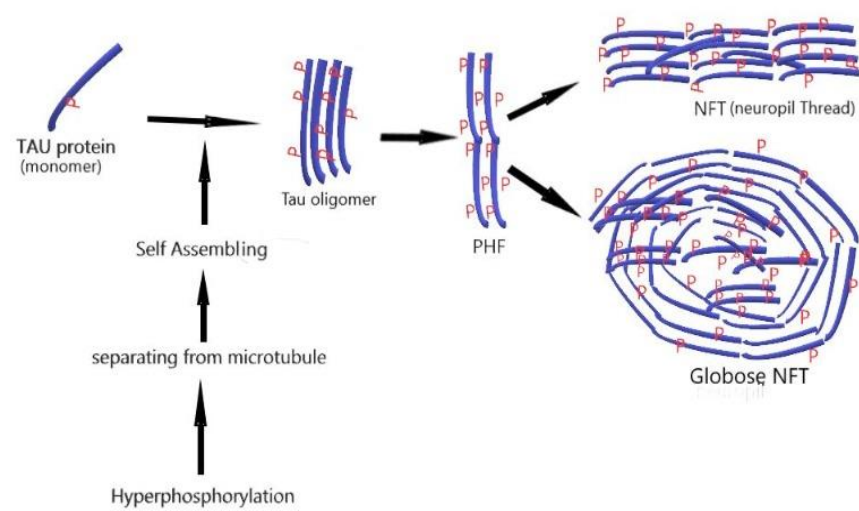

p hyperphosphorylation

شكل ع. مراحل هاييرفسفريلاسيون و فرمهاى رسوبى تاو يروتئين. بعد از فسفريله شدن مونومرهاى تاو يروتئين توسط يروتئين كينازها، مونومرهاى هايبرفسفريله از

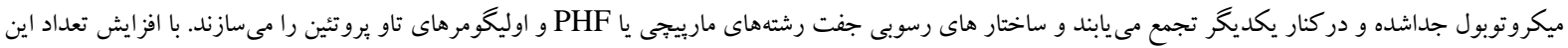

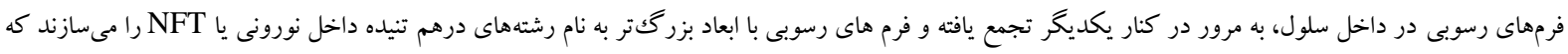
مى تواند بهصورت كروى و يا رشتهاى درهم تنيده باشد. Neurofibrilary Tangle, NFT Paired Helical Filament, PHF.

درهم يِيجيده داخل نورونى در اين نواحى باعث مىشود كه عملكرد نورونهاى لايههاى داخلى قشرى تا حد زيادى كم

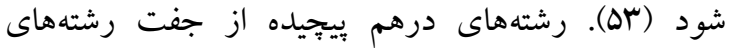
ماريبيجى تشكيل مى شوند كه در دندريتها حضور دارند و در مراحل اوليهى آسيب عصبى تشكيل مىشوند (WF، در مرحلهى قبل از تجمع رشتههاى درهم يِيجيده داخل نورونى، تاو بروتئين هايبرفسفريله را كه در دندريتها و در ناحيه جسم سلولى يافت مىشود، ييشتنيده مى گويند كه در مراحل بعدى اولين تجمعات قابل تشخيص در دندريتها ديده مىشود و بعد از آن رشتههاى در هم ييجيده يا در هم تنيده داخل نورونى در جسم سلولى تشكيل مىشود (DF) هاه). امروزه شناخت نوع ايزوفرمى از تاو يروتئين كه در بدن شخص بيمار رسوب كرده است نيز بسيار حائز اهميت است جرا كه مىتوان از آن به عنوان شناساگر زيستى استفاده كرد و بيمارهاى مختلف ناشى از تجمع تاو يروتئين را از يكديگر تشخيص داد. در افراد مبتلا بيمارى آلزايمر هر دو ايزوفرم با انتهاى 3R و 4R از تاو يروتئين در تجمعهاى رسوب يافته از اين بروتئين ديده مىشود؛ اما در تحليل
بيمارىزايى تاو برو تئين در بيمارى آلز ايمر: بيمارى آلزايمر يكى از بيمارىهاى تحليل برنده عصبى است كه حدود شش درصد از جمعيت بالاى 90 سال را تحت تأثير قرار مىدهد و با افزايش سن افراد نيز شيوع آن بيشتر مىشود ( •ه). علاوه بر رسوب بروتئينهاى آميلوئيد بتا به شكل پِلاككهاى آميلوئيدى، تجمع تاو پِروتئين هايبر فسفريله به شكل رشته هاى درهم بيبحِيده داخل نورونى از عوامل اصلى آسيب به سلولهاى عصبى و القاى بيمارى آلزايمر هستند ( (ها). تجمع تاو يروتئين بيمارىزا در بيمارى آلزايمر فقط در نورونها ديده مى شود در حالى كه در ساير بيمارىهاى ناشى از تاو بروتئين، سلولهاى كليال نيز تحت تأثير قرار مى گيرند. تجمع تاو بروتئين در ناحيهى جسم سلولى به صورت رشته هاى در هم بييجيده داخل نورونى يا در دندريتها به عنوان نوروييلها و در آكسونها به حالت پيلاككهاى عصبى تاجىشكل ديده مىشود (OY). رشته هاى درهم يبيجيده داخل نورونى را معمولاً مى توان در ناحيهى سلولهاى هرمى هيِ كامب، قشر انتورينال (Entorhinal cortex) ايزوكورتكس مشاهده كرد. در نتيجه، حضور رشتهاى 
شهس الدين امهدى وسر

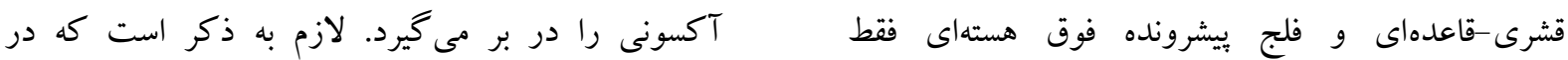
ايزوفرمهاى با انتهاى 4R تاو بروتئين ديده مىشود. دلايل بيمارىهاى تحليل قشرى-قاعدهاى و فلج يشرونده فوق هستهاى، تجمع فرمهاى رسوبى تاو بروتئين علاوه بر سلول

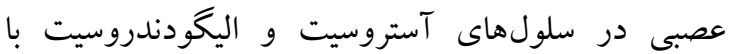
مولكولى تجمع و رسوب تاو يروتئين در نواحى مختلف بهرئ الكوى خاصى در هر بيمارى ديده مىشود (شكل ه) (ه9)، سلولى يافت نشده است. در بيمارى آلزايمر، رسوب تاو يروتئين فقط در سلول عصبى وجود دارد و تمامى نواحى

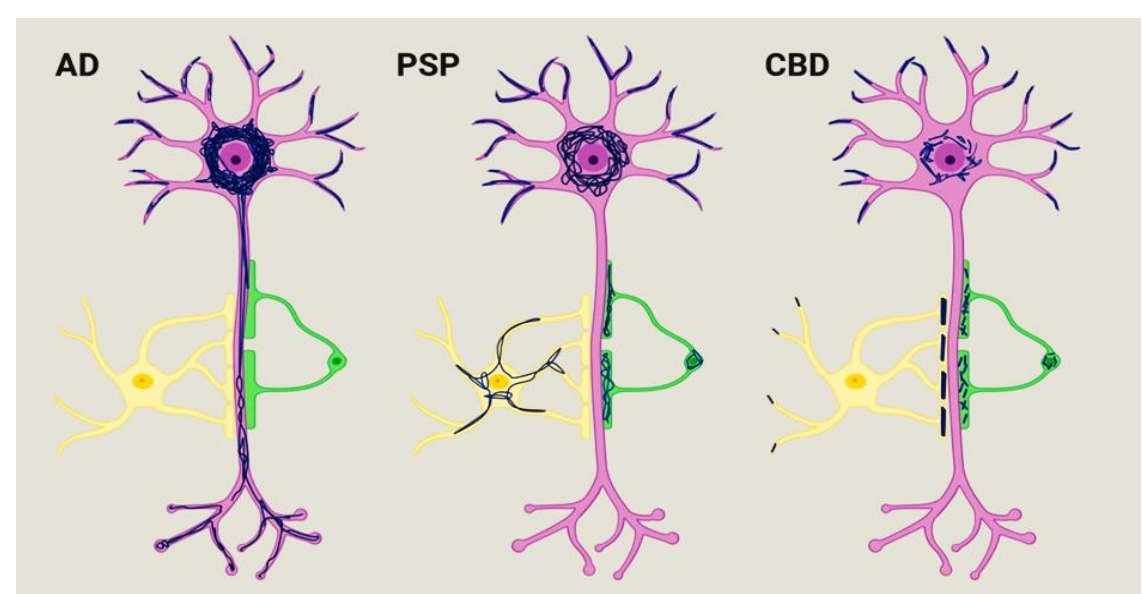

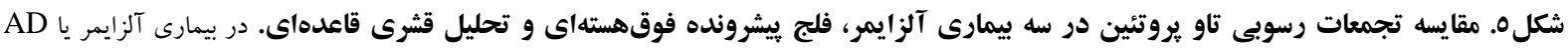

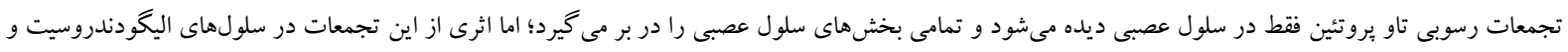

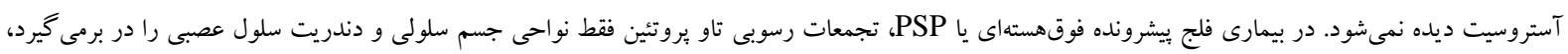

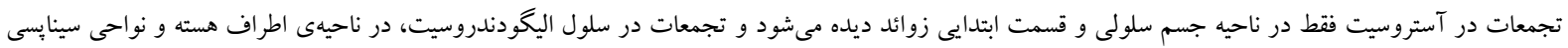

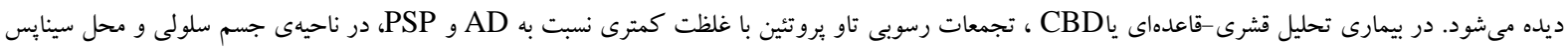

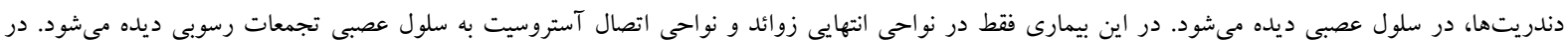

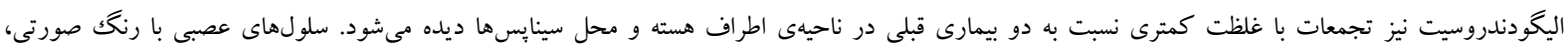

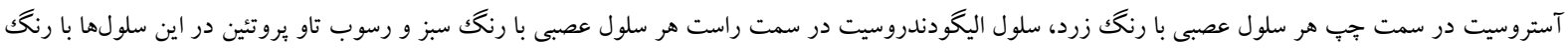

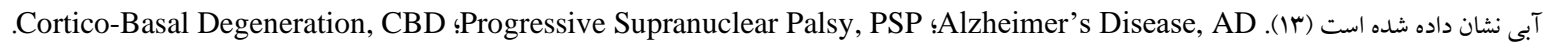

مىدهند. مرحلهى يك و دو را كذر از قشر انتورينال مىنامند كه در اين مرحله تاو يروتئينى بيمارىزا از ناحيهى اطر اف قشر انتورينال به هييو كامٍٍ منتقل مىشود. مرحلهى سه و جهار را مرحلهى سيستم ليمبيك مى گويند كه در اين

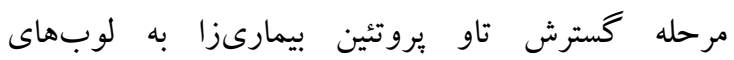
كيجگاهى، ييشانى و آهيانه در قشر مخ مىرسد. مرحله بنج و شش را مرحله ايزوكورتكس مى

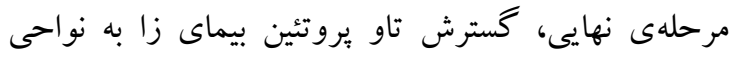
حسى و غير حسى در قشر مخ مىرسد (هN). همجنين در
توزيع تاو يروتئين بيمارىزا در دستگاه عصبى بيماران

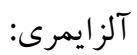
در بيمارى آلزايمر، تاو يروتئين بيمارىزا در ابتدا در نواحى بسيار براكنده از مغز حضور دارد و بعد از آن بر اساس يكك

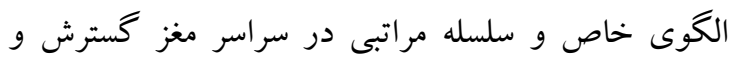

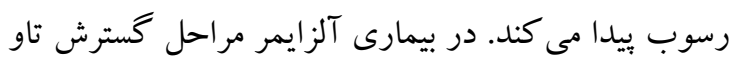
يروتئين هاييرفسفريله و رسوب آن و درگير شدن نواحى مختلف مغز، به شش مرحله تقسيم شده است كه آنها را با

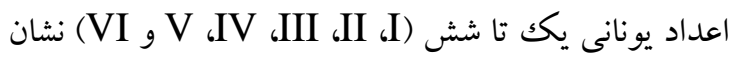

هبلم علمى دانشكاه علوه يِشكى كردستان / دوره بيست و شش / درداد و شهريور م.ع|| 
TREM2 تعدادى از زنها ماند زن بيان كنندهى مولكول (Triggering receptor expressed on myeloid كه در بيمارى آلزايمر دخالت دارد، در اين cells 2) سلولها بيان مىشوند (99، 9V). در بيمارىهاى مرتبط با ميكرو كليا مانند بيمارى آلزايمر، بيان لييويروتئينهايى مانند آيوليويروتئين E (Apolipoprotein E, ApoE) نيز افزايش مىيابد (91). ApoE يكك انتقالدهندهى ليبيدى است كه وظيفهى انتقال بر گشتى كلسترول از سلولهاى محيطى به كبد را جهت ترشح مجدد بر عهده دارد. ApoE در مغز به صورت اختصاصى وظيفهى انتقال ليييدهايى مانند كلسترول را بين سلولهاى عصبى و گليال برعهده دارد (99، (V.). علاوه بر اين، حامل هاى لييويروتئينى مانند ApoE و كلاسترين (Clusterin) مى تو انند با گيرنده اختصاصى در

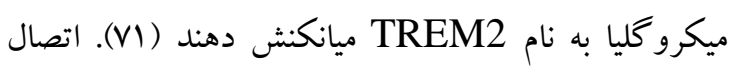
ApoE به گيرنده TREM2 اثر مستقيمى بر تنظيم بيان زن بـ

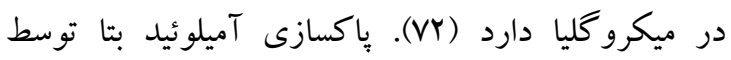

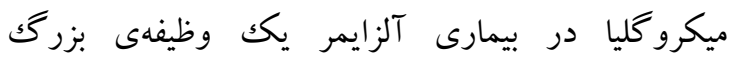

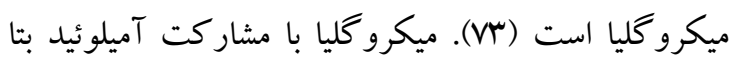
نقش مستقيمى در افزايش ميزان تاو بروتئين بيمارىزا دارد. همجينين نقش ميكرو گليا در گسترش بيمارىزايى تاو يروتئين بعد از آزادسازى آن از سلول عصبى گزارش شده است (VF). اما القاى فعاليتهاى زنتيكى در ميكرو كليا، سبب سرعت بخشيدن به بيمارى زايى تاو بروتئين مى (VD V V V )

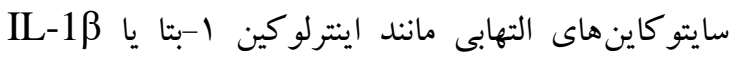

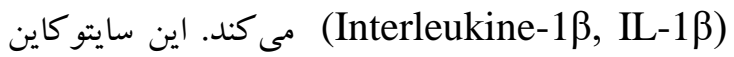
به گيرنده اينترلو كين ا-بتا موجود بر روى سلولهاى عصبى متصل مىشود و اين اتصال سبب فعالشدن كيناز (p38 Mitogen-Activated p38MAPK Protein Kinase, p38 MAPK) كيناز نيز در نهايت سبب هاييرفسفريلاسيون تاو يروتئين
نمونهاى مورد آزمايش، مشخص شده است كه رشتهاى يروتئينى ييشتنيده و در هم تنيده قبل از مرحلهى انتورينال در عقدهاى قاعدهاى (Basal ganglia) نيز يافت شده

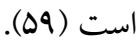
علائم بالينى اوليهى بيمارى آلزايمر مانند استفاده نادرست از كلمات در جملهها و اشتباه در زمان و مكان در مراحل III

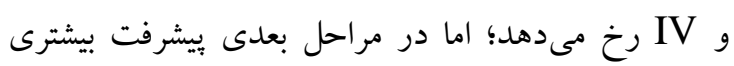

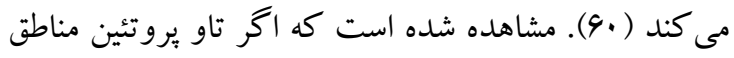
متعددى در مغز را درگير كند، نسبت به حالتى كه در يكك نقطه از مغز تجمع يابد، اثرات تخريبى و اختلالات بيشترى را ايجاد مى كند (1). علاوه بر مناطقى كه ذكر شد، مىتوان تاو يروتئين را در هييوتالاموس، تالاموس، سيستم بويايى، سيستم ليمبيك و سيستم حسى-حركتى بيماران آلزايمرى نيز مشاهده كرد (GY). بيمارى آلزايمر باعث ايجاد تغييرات ساختارى و در نتيجه سبب افزايش فعاليت كينازهاى ثانويه و تشكيل يككسى ايى توٍ مىشود. براى مثال يك إيىتوب شناسايى شده توسط آنتىبادى AT100 در جفت رشتهاى مارييجى يافت شده است كه در نتيجه يك فسفريلاسيون متوالى توسط GSK-3 و وبروتئين كيناز A بر روى جايگاه ترئونين YlY و سرين F/F به همراه آمينو اسيدهاى فسفريلهى

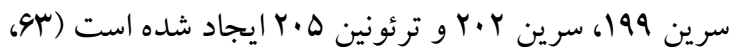

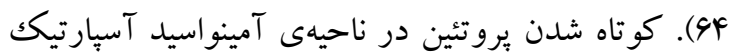
اسيد مىتواند باعث تغيير از يك حالت با خاصيت حلاليت بالا به يكك حالت متفاوت تجميع شونده مانند اوليكومر يا ييش سازهاى يِيجخوردهاى شود كه در نهايت سبب توليد ساختارهاى ثانويهاى مانند ابیىتوبِهاى قابل شناسايى توسط آنتىبادىهاى AT100 و ALZ50 شود (90). ميكرو كلياها به عنوان سلول ايمنى موجود در مغز، به همراه التهابهاى عصبى در گسترش بيمارى آلزايمر نقش دارند. 
تشكيل فرمهاى تجمعى آن معرفى شده است؛ اما روشن شدن نقش آنها در توليد ميزان تاو بروتئين و القاى بيمارى آلزايمر نياز به مطالعات بيشترى دارد (VN). شواهدى اخيراً كزارش شده است كه ويتامين D با كاهش توليد سايتو كينهاى التهابى، مىتواند از القاى التهاب و آسيب به

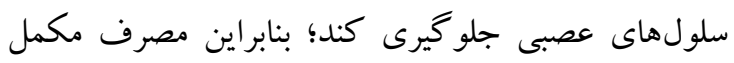

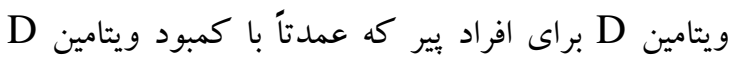
مواجه هستند، مىتواند از خطر رسوب تاو يروتئين و آميلوئيد بتا و ابتلاى به آلزايمر بكاهد (Vq).
مىشود (VA VF)؛ بنابراين آميلوئيد بتا كه در بيمارى آلزايمر افزايش مىيابد، مىتواند با تحريك فعاليت ميكرو كلياها سبب توليد سايتو كاين از اين سلولهاى كليال و به طور غير مستقيم موجب افزايش ميزان تاو بروتئين هاييرفسفريله شود (V9). توليد مولكولهاى ApoE و TREM2 به همراه آميلوئيد بتا نيز سبب القاى فعاليت ميكرو كليا در توليد سايتو كاينها مىشوند (شكل 9) (VV). در سالهاى اخير نقش عوامل مولكولى ديخرى مانند RNA مختلف و تأثير بر ميزان هاييرفسفريلاسيون تاو بروتئين و

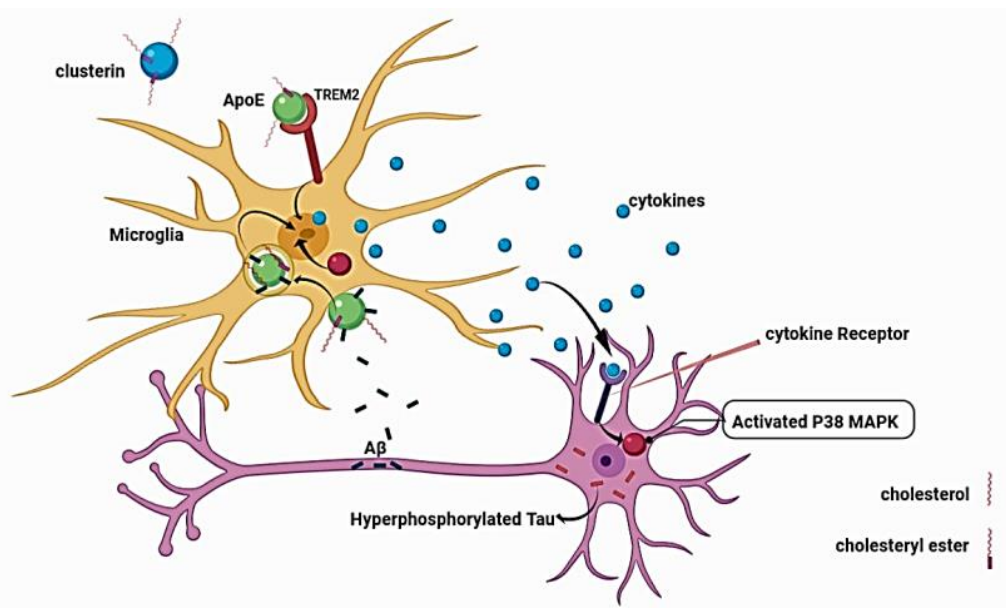

شكل T. ارتباط آميلوئيد بتا و ميكروكليا در ميزان توليد تاو يروتئين هاييرفسفريله. ApoE و كلاسترين با تحريك TREM2 سبب تغيير در فعاليت ميكرو كليا

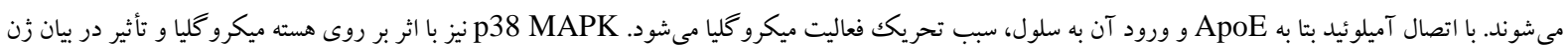

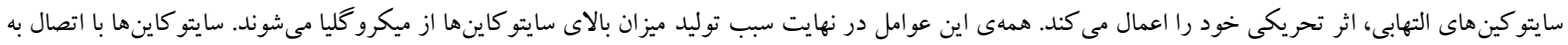

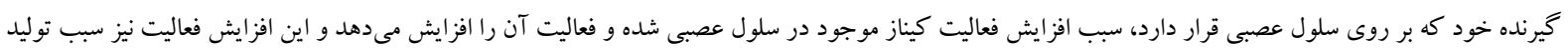

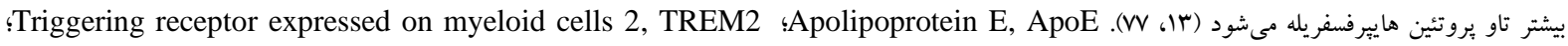
p38 Mitoen Activated Protein Kinase, p38 MAPK ؛Amyloid Beta, A $\beta$

كبودى، بى حسى يا بى حالى و بىنظمى در راه رفتن بودند. آنها اين بيمارى را با از دست دادن سلولهاى عصبى و تورم اين سلولها معرفى كردند (·A). اين بيمارى بعداً در سال 1919 توسط گيب (Gibb) به نام تحليل قشرى-

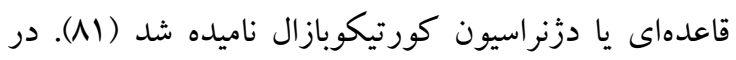
اين بيمارى، سلولهاى عصبى نواحى قشرى بيشانى و بس سرى تحليل مىروند. همجنين در نواحى زير قشرى مغز

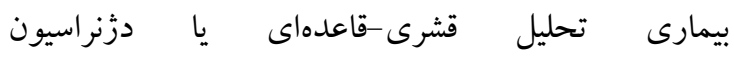
Cortico-Basal Degeneration, كورتيكوبازال : (CBD بيمارى تحليل قشرى-قاعدهاى يا دزنراسيون كورتيكوبازال براى اولين بار توسط ربيز (Rebeiz) و همكارانش در سال 1991 معرفى شد. افراد بيمار مورد مطالعه ايشان داراى نشانهايى از لرزش، كند شدن حركت دست و يا، سفتى، هبلم علمى دانشكاه علوه يِشكى كردستان / دوره بيست و شش / درداد و شهريور م.ع| 
رعاן بيمارى أيى كونه هاى هذتلف...

كاهى بر اين اساس متخصصين مغز و اعصاب به جاى وازه بيمارى به اين اختلال عصبى، سندروم قشرى-قاعدهاى مى گويند. بر اساس راهنمايىهاى منتشر شده توسط انجمن

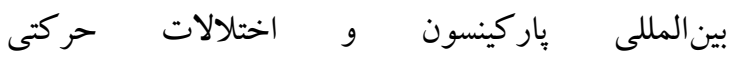
(International Parkinson and Movement disorder) بدن ديده مىشود. علائم شايع در بيمارى تحليل قشرىقاعدهاى در جدول ا خلاصه شده است (Fی)،
افر اد مبتلا به اين بيمارى، سلولهاى عصبى متورم يافت شده است. علاوه بر نواحى قشرى، نواحى ديخرى در مغز مانند هستهى قرمز (Red Nucleus)، تالاموس و عقدههاىهاى قاعدهاى نيز در اين بيمارى درگير هستند (AY). عوارض ناشى از آسيب به اين نواحى مغزى به شكل اختلالات مختلف حركتى، حسى و شناختى در افراد بيمار ظاهر مىشود. علائم بيمارى تحليل قشرى-قاعدهاى با ساير بيمارىهاى تحليل برنده عصبى هميوشانى زيادى دارد و

جدول ا. علائم شايع در بيمارى تحليل قشرى-قاعدهاى (rی،، AF)

\begin{tabular}{|c|c|}
\hline علائم بيمارى & رديف \\
\hline كند شدن حر كات و سفتى گردن، دستها و باها & 1 \\
\hline اختلال در راه رفتن و حفظ تعادل به نحوى كه ممكن است باعث زمين خوردن شود. & r \\
\hline انقباض ها و يرشهاى عضلانى كه ميو كلونوس (Myoclonus) ناميده مىشوند. & r \\
\hline مشكل در انجام حر كات معمول دست و پيا & r \\
\hline از بين رفتن حس يكك سمت بدن يا اشكال در تشخيص اجسام با لمس كردن & $\Delta$ \\
\hline احساس اينكه يك دست خودش تصميم مى گيرد كه به آن 》دست بيكانه (Alien hand )) كفته مى شود. & 4 \\
\hline اختلال در زبان و تكلم مانند اختلال در ييدا كردن كلمات درست در هنگام صحبت كردن & $\checkmark$ \\
\hline اختلالات رفتارى ماند از دست دادن هيجان و تمايل به فعاليت، اختلال شخصيت، تحريك يذيرى و بىقرارى & $\wedge$ \\
\hline
\end{tabular}

آلزايمر و فلج ييشرونده فوق هستهاى در نواحى جسم سلولى و محل سينايس دندريتهاى سلول عصبى ديده مىشود. در اين بيمارى فقط در نواحى انتهايى زوائد و نواحى اتصال آستروسيت به سلول عصبى تجمعات رسوبى ديده مىشود. در اليگودندروسيت نيز تجمعات با غلظت كمترى نسبت به دو بيمارى قبلى در ناحيهى اطراف هسته و محل سينايس ها ديده مى شود (D9). اين فرضيه مطرح شده است كه ناهنجارى در فرم هايلوئيد H1 در كروموزوم شمارهى IV عامل ايجاد بيمارى تحليل قشرى-قاعدهاى است. اين فرضيه در DV مورد از بيمارانى كه آسيب عصبى داشتهاند، تائيد شده است و در مواردى كه تشخيص بالينى داشتهاند، ارتباط بين اختلال در كروموزوم VI و اين بيمارى يافت شده است (AN، (MV).
نقش تاو بروتئين در بيمارى تحليل قشرى-قاعدهاى: به طور كلى امروزه مشخص شده است كه بيمارى تحليل قشرى-قاعدهاى يكى از بيمارىهاى تحليل برنده عصبى است كه با تجمع تاو بروتئين هايبرفسفريله مشخص مىشود. در اين بيمارى، رشتههاى غير طبيعى تاو بروتئين به شكل جفت رشتهاى مارييجى در مى آيند و مىتوان آنها را در

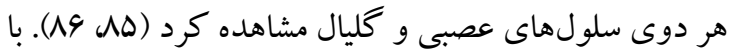
بررسى تجمعات يروتئينى در اين بيمارى مشاهده شده است كه عموماً اكزون شمارهى سه در ايزوفرمهاى تاو يروتئين وجود ندارد (ه) و فقط ايزوفرمهاى تاو بروتئين با انتهاى 4R ديده شده است در حالى كه ايزوفرمهاى با انتهاى 3R، فقط در تاو بروتئين رسوب كرده در بيمارى آلزايمر وجود دارد (AF). در بيمارى تحليل قشرى-قاعدهاى، تجمعات رسوبى تاو بروتئين با غلظت كمترى نسبت به بيمارى 
بيمارى در بين افراد، بنج تا شش مورد در هر صد هزار نفر است (•9). اين بيمارى باعث بروز علائم مختلفى مىشود

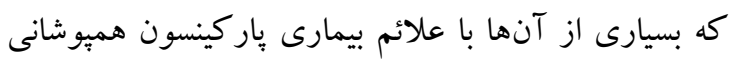
دارد و به همين دليل اين بيمارى را باركينسون غيرمعمول نيز مىنامند؛ اما شيوع آن (Atypical parkinsonism) يكك دهم بيمارى باركينسون است (19). علائم شايع بيمارى فلج ييشرونده فوق هستهاى بر اساس راهنمايىهاى منتشر شده توسط انجمن بينالمللى پِاركينسون و اختلالات حر كتى، در جدول r خلاصه شده است (Yq، ra). يزشكان در بيمارى فلج بيشرونده فوقهستهاى با تجويز بيشسازهاى دويامين مىتوانند علائم حر كتى بيمارى را بهبود ببخشند؛ اما با پيشرفت بيمارى به دليل از بين رفتن ناحيهى يس سينايسى در نورونهاى اجسام مخطط، پاسخهاى ضعيفى

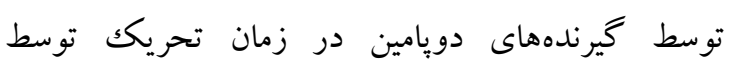
آكونيست هاى دويامينى مشاهده مى شود (9)، 94).
بيمارى فلج بيشرونده فوق هستهاى Progressive) Supranuclear Palsy, PSP) بيمارى فلج بيشرونده فوق هستهاى يا PSP يكك اختلال عصبى بيشرونده است كه توسط استيل (Steele)

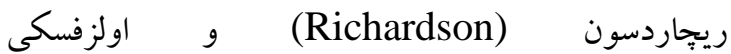
در سال 1994 معرفى شد و آن را سندرم (Olszewski) استيل-ريجاردسون-اولزفسكى نيز مىنامند. بيمارانى كه اين دانشمندان بر روى آنها مطالعه مى كردند داراى علائمى شامل بىثباتى وضعى، اختلال حركتى جشم، اختلال در

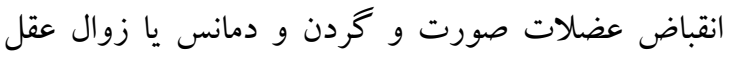
بودند. اين دانشمندان وجود اجسام درون سلولى كروى يا شعلهاى شكلى را در ماده خاكسترى و سفيد سراسر ساقه مغز، نواحى زير قشرى (هستهاى زير تالاموسى و عقدهاى

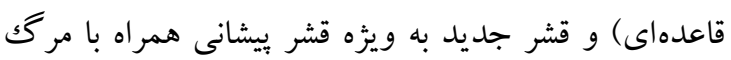
سلولى و تحليل رفتن ماده سفيد مشاهده كردند (19). اين

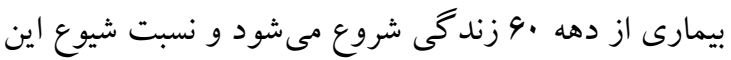

جدول r. علائم شايع در بيمارى فلج ييشرونده فوق هستهاى (Y a، ra)

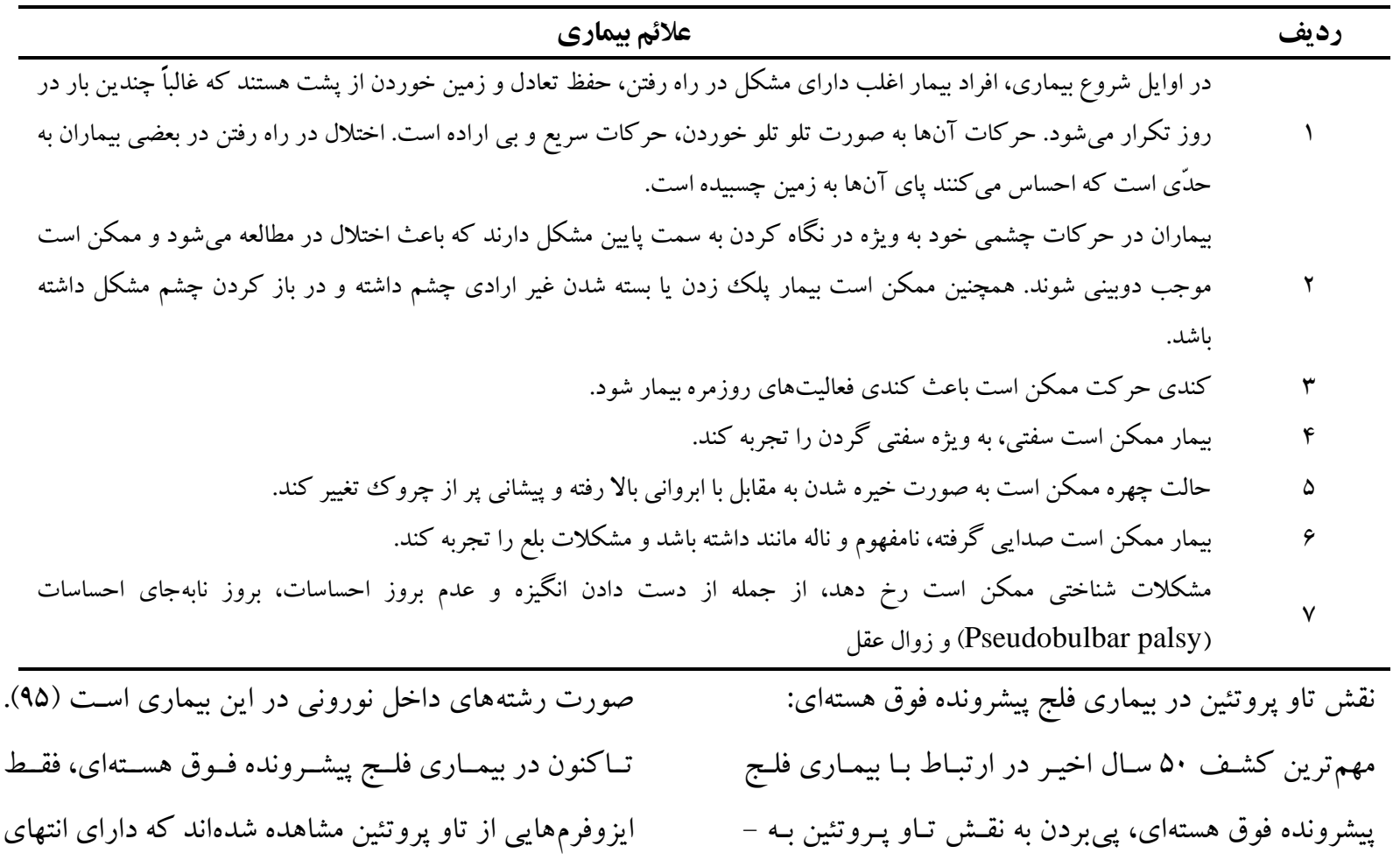

هبلم علمى دانشكاه علوه يِشكى كردستان / دوره بيست و شش / درداد و شهريور م.ع|| 
در حال ساختن مهار كنندهاى ايـن كينـاز بـا هــف كنتـرل توليد شكلهاى بيمارىزاى تاو بروتئين هستند (91). دو بيمارى تحليل قشرى-قاعدهاى و فلج ييشرونده فوق هستهاى نيز بسيار شبيه به هم هستند؛ اما با بررسى محل تجمع تاو بروتئين رسوب يافته در سلولهاى عصبى و گليال

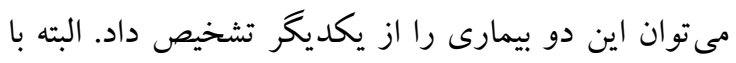
بررسى علائم بالينى نيز مىتوان اين دو بيمارى را تا حدى از هم تفكيكك نمود. با توجه به اين كه بيمارى فلج ييشرونده فوق هستهاى داراى فنوتي؛هاى متفاوتى است، مىتوان

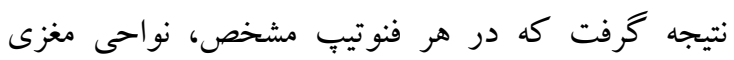
درگير نيز تا حدودى متفاوت است و بيى بردن دقيق به اين نواحى مى تواند در كنترل و درمان علائم ناشى از آن مؤثر باشد. اختلالات گفتارى و رفتارى در ميان اكثر فنوتيبهاى بيمارى فلج بيشرونده فوق هستهاى مشترك است و اين موضوع مى تواند تا حدى كار تشخيص فنوتيب را بر اساس علائم بالينى سخت كند. متخصصين مغز و اعصاب بيمارى فلج ييشرونده فوقهستهاى را بر اساس علائم بالينى و فنوتيبهاى ظاهرى به جند دسته تقسيم كردهاند كه در جدول-r خلاصه شده است (99، ..1).
4R هستند و ايزوفرمهايى با انتهاى 3R مشاهده نشده است. اين رسوبات در سلولهاى عصبى و كليـال ديـده مىشوند. تجمعات رسوبى تاو يروتئين در سلول عصبى، جسم سـلولى

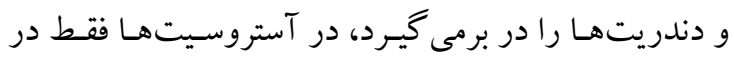
ناحيه جسم سلولى و قسمت ابتدايى زوائد ديــه مى شـود در حالى كه در سلول اليكودندروسيت، تجمعات در ناحيهى اطر اف هسته و نواحى سينايسى ديده مى شود. از اين موضوع مى توان به عنوان يكك مشخصـه اختصاصى بـراى تشـخيص ايـن بيمـارى از سـاير بيمارىهـاى تحليـل برنسـده عصسبى و حر كتى مانند بيمارى آلزايمـر و بار كينسـون استفاده نمـود. ايجاد جهشهايى در ساختار زنتيكى كه منجر به توليد بالاى ايزوفرم 4R از تاو بروتئين شود، مىتواند سبب تشديد ايـن

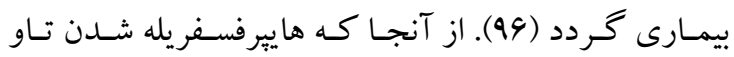
يروتئين موجب جدا شدن آن از ميكروتوبول، تشكيل جفت رشتهاى مارييجى و رسوب تاو مى گردد، نقش كينازهـاى

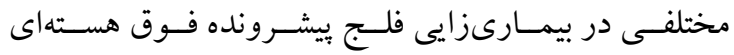

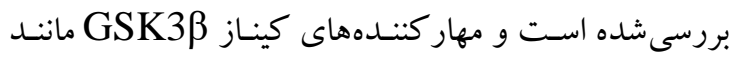
ليتيـوم و واليرويـك اسـيد در مــلهاى حيـوانى تـا حسدى

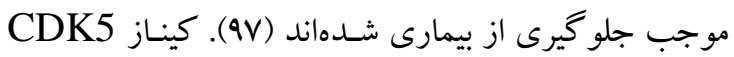
نيز موجب فسفريله شدن تاو بـروتئين مىشـود و دانشـمندان

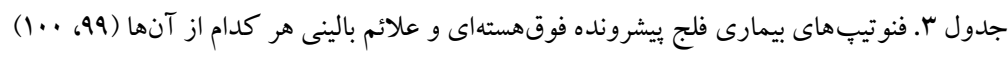

\begin{tabular}{|c|c|c|c|}
\hline مهممترين علائم بالينى & 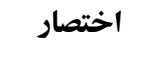 & انواع فنو تي؟ & 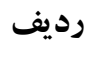 \\
\hline \multirow{2}{*}{\multicolumn{4}{|c|}{ ايستال عملكردى حر كتى جشم، بىثباتى و عدم يايدارى در }} \\
\hline & & & \\
\hline اختلالات حر كات جشم & PSP-OM & PSP-ocular motor & r \\
\hline عدم بِايدارى و بى ثباتى در ايستادن & PSP-PI & PSP-postural instability & $r$ \\
\hline علائم شبه پِاركينسون & PSP-P & PSP-parkinsonism & $\varepsilon$ \\
\hline اختلالات حر كتى و رفتارى & PSP-F & PSP-frontal & 0 \\
\hline اختلال در راه رفتن و توقف تدريجى در زمان حركت & PSP-PGF & PSP-progressive gait freezing & 7 \\
\hline علائم شبيه بيمارى CBD & PSP-CBS & PSP-corticobasal syndrome & $\checkmark$ \\
\hline 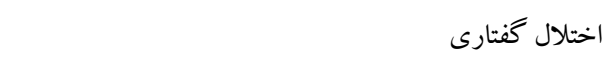 & PSP-SL & PSP-speech/language disorder & $\wedge$ \\
\hline
\end{tabular}


شود. با افزايش اميد به زندگى و افزايش جمعيت سالمند در كشور و نيز با كسترش روز افزون مبتلايان به بيمارىهاى عصبى مرتبط با تاو بروتئين در دوران بيرى، افزايش اطلاعات در مورد اين يروتئين براى تشخيص زود هنكام بيمارىهاى مرتبط با تاو بروتئين و انجام درمانهاى مؤثرتر بسيار مهم است. با يافتن راهى براى كنترل كامل فرايندهايى كه منجر به فسفريلاسيون تاو بروتئين مىشوند و همجنين تمركز بر عوامل تشديد كنندهى بيمارى مانند فعال شدن ميكرو كلياها و توليد عوامل التهابى، مىتوان تحول بسيار عظيمى را در درمان بيمارىهاى ناشى از اين يروتئين ايجاد كرد و ضمن افزايش ميزان اميد به زندگى در ميان اين افراد، مى توان زندگى راحت ترى را براى افراد مبتلا، خانو ادههاى آنها و جامعه فراهم نمود. اين مهم به صرفهويى در هزينهاى بهداشتى كشور براى نخهدارى و مراقبت از سالمندان نيز كمك شايانى خواهد نمود. اميد است بال بهائ بررسى هرجه بيشتر فرايندهاى مولكولى دخيل در بيمارىهاى تحليل برنده عصبى، متخصصان مغز و اعصاب

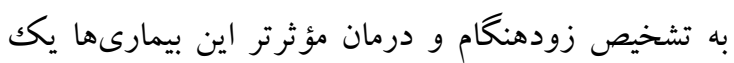

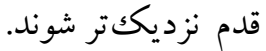

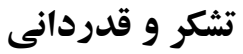

اين مطالعه با حمايت معاونت يزوهش و وفناورى دانشكاه كردستان از نويسنده مسئول مقاله انجام شده است (كرانت

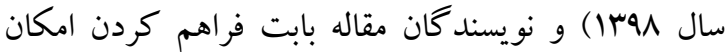
دسترسى به متن كامل مقالات مورد استفاده در اين مطالعه مرورى، از معاونت بيزوهش و فناورى دانشگاه كردستان تشكر و قدردانى مىنمايند. هيجِكدام از نويسند مطالعه، تعارض منافعى براى انتشار اين مقاله ندارند. لازم به

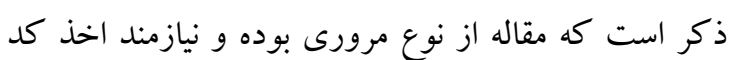
اخلاق نبوده است.
نتيجه كيرى

اكرجهه فسفريله شدن در تاو بروتئين يك فرآيند طبيعى است و براى عملكرد طبيعى تاو يروتئين و يويايى ميكروتوبول لازم است؛ اما در اثر افزايش فعاليت كينازهاى مختلف و هايبرفسفريله شدن تاو بروتئين تحت شرايط خاصى كه در بخش فسفريله شدن تاو يروتئين به آنها اشاره شد، احتمال تشكيل فرمهاى رشتهاى تاو بروتئين و رسوب تجمعات اين رشتها در هر دوى سلولهاى عصبى و سلولهاى گليال وجود دارد. امروزه مشخص شده است كه بيمارىهاى عصبى مختلفى در اثر رسوب تاو يروتئين در سلولهاى عصبى و كليال ايجاد مىشوند. از جمله بيمارىهاى تحليل برنده عصبى كه تاو يروتئين در ايجاد آنها نقش قابل توجهى دارد مىتوان به بيمارى آلزايمر، تحليل قشرى-قاعدهاى و فلج بيشرونده فوق هستهاى اشاره نمود. لازم به ذكر است كه تاو يروتئين در بيمارىهاى

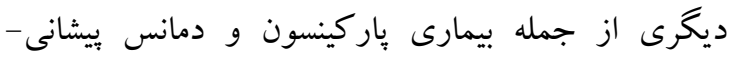

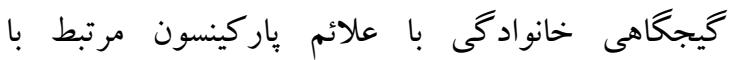
كروموزوم Frontotemporal dementia with IV parkinsonism linked to chromosome 17, نيز نقش دارد. محل رسوب تاو يروتئين در FTDP17) داخل سلولها عصبى و كليال و نيز در نواحى مغزى مختلف در هر يك از اين بيمارىها متفاوت است. از آنجا كه عامل اصلى رسوب تاو بروتئين، فسفريله شدن بيش از حد آن و جدا شدن از ميكروتوبولها و در نتيجه بدشكل شدن اسكلت سلولى در سلولهاى عصبى و گليال است؛ بنابر اين شناخت نواحى فسفريلهشن بر روى تاو بروتئين و عوامل مؤثر در فسفريله شدن آن ماند كينازهاى مختلف مىتواند كمك بزركى براى حل مشكل بيمارىهاى ناشى از اين

$$
\text { بروتئين به شمار آيد. }
$$

با توجه به نقش بسيار مهم تاو بروتئين در اختلالات عصبى لازم است كه تحقيقات وسيع تر و بيشترى در اين زمينه انجام 
1.Goedert M, Spillantini MG, Jakes R, Rutherford D, Crowther RA. Multiple isoforms of human microtubule-associated protein tau: sequences and localization in neurofibrillary tangles of Alzheimer's disease. Neuron. 1989;3(4):519-26.

2.Nisbet RM, Polanco JC, Ittner LM, Gotz J. Tau aggregation and its interplay with amyloid-beta. Acta Neuropathol. 2015;129(2):207-20.

3.Ennulat DJ, Liem RK, Hashim GA, Shelanski ML. Two separate 18-amino acid domains of tau promote the polymerization of tubulin. J Biol Chem. 1989;264(10):5327-30.

4.Violet M, Delattre L, Tardivel M, Sultan A, Chauderlier A, Caillierez R, et al. A major role for Tau in neuronal DNA and RNA protection in vivo under physiological and hyperthermic conditions. Front Cell Neurosci. 2014;8:84.

5.Marciniak E, Leboucher A, Caron E, Ahmed T, Tailleux A, Dumont J, et al. Tau deletion promotes brain insulin resistance. J Exp Med. 2017;214(8):2257-69.

6.Frandemiche ML, De Seranno S, Rush T, Borel E, Elie A, Arnal I, et al. Activity-dependent tau protein translocation to excitatory synapse is disrupted by exposure to amyloid-beta oligomers. $\mathbf{J}$ Neurosci. 2014;34(17):6084-97.

7.Feng Q, Luo Y, Zhang XN, Yang XF, Hong XY, Sun DS, et al. MAPT/Tau accumulation represses autophagy flux by disrupting IST1-regulated ESCRT-III complex formation: a vicious cycle in Alzheimer neurodegeneration. Autophagy. 2020;16(4):641-58.

8.Laurent C, Buee L, Blum D. Tau and neuroinflammation: What impact for Alzheimer's Disease and Tauopathies? Biomed J. 2018;41(1):21-33.

9.Drechsel DN, Hyman AA, Cobb MH, Kirschner MW. Modulation of the dynamic instability of tubulin assembly by the microtubule-associated protein tau. Mol Biol Cell. 1992;3(10):1141-54.

10.Andreadis A, Brown WM, Kosik KS. Structure and novel exons of the human tau gene. Biochemistry. 1992;31(43):10626-33.

11.Weingarten MD, Lockwood AH, Hwo SY, Kirschner MW. A protein factor essential for microtubule assembly. Proc Natl Acad Sci U S A. 1975;72(5):1858-62.

12.Miguel L, Rovelet-Lecrux A, Feyeux M, Frebourg T, Nassoy P, Campion D, et al. Detection of all adult Tau isoforms in a 3D culture model of iPSC-derived neurons. Stem Cell Res. 2019;40:101541.

13.Arendt T, Stieler JT, Holzer M. Tau and tauopathies. Brain Res Bull. 2016;126(Pt 3):238-92.

14.Morris M, Knudsen GM, Maeda S, Trinidad JC, Ioanoviciu A, Burlingame AL, et al. Tau posttranslational modifications in wild-type and human amyloid precursor protein transgenic mice. Nat Neurosci. 2015;18(8):1183-9.

15.Kar S, Fan J, Smith MJ, Goedert M, Amos LA. Repeat motifs of tau bind to the insides of microtubules in the absence of taxol. Embo j. 2003;22(1):70-7.

16.Al-Bassam J, Ozer RS, Safer D, Halpain S, Milligan RA. MAP2 and tau bind longitudinally along the outer ridges of microtubule protofilaments. J Cell Biol. 2002;157(7):1187-96.

17.Janning D, Igaev M, Sundermann F, Bruhmann J, Beutel O, Heinisch JJ, et al. Single-molecule tracking of tau reveals fast kiss-and-hop interaction with microtubules in living neurons. Mol Biol Cell. 2014;25(22):3541-51.

18. Chen J, Kanai Y, Cowan NJ, Hirokawa N. Projection domains of MAP2 and tau determine spacings between microtubules in dendrites and axons. Nature. 1992;360(6405):674-7.

19.Alonso A, Zaidi T, Novak M, Grundke-Iqbal I, Iqbal K. Hyperphosphorylation induces selfassembly of tau into tangles of paired helical filaments/straight filaments. Proc Natl Acad Sci U S A. 2001;98(12):6923-8.

20.Hanger DP, Seereeram A, Noble W. Mediators of tau phosphorylation in the pathogenesis of Alzheimer's disease. Expert Rev Neurother. 2009;9(11):1647-66.

21.Sergeant N, Bretteville A, Hamdane M, Caillet-Boudin ML, Grognet P, Bombois S, et al. Biochemistry of Tau in Alzheimer's disease and related neurological disorders. Expert Rev Proteomics. 2008;5(2):207-24.

22.Martin L, Latypova X, Wilson CM, Magnaudeix A, Perrin ML, Yardin C, et al. Tau protein kinases: involvement in Alzheimer's disease. Ageing Res Rev. 2013;12(1):289-309. 
شعس الدين امددى

23.Wang L, Jiang Q, Chu J, Lin L, Li XG, Chai GS, et al. Expression of Tau40 induces activation of cultured rat microglial cells. PLoS One. 2013;8(10):e76057.

24.Braak H, Braak E. Neuropathological stageing of Alzheimer-related changes. Acta Neuropathol. 1991;82(4):239-59.

25.Ubersax JA, Ferrell JEJ. Mechanisms of specificity in protein phosphorylation. Nat Rev Mol Cell Biol. 2007;8(7):530-41.

26.Baumann K, Mandelkow EM, Biernat J, Piwnica-Worms H, Mandelkow E. Abnormal Alzheimerlike phosphorylation of tau-protein by cyclin-dependent kinases cdk2 and cdk5. FEBS Lett. 1993;336(3):417-24.

27. Olsson B, Lautner R, Andreasson U, Ohrfelt A, Portelius E, Bjerke M, et al. CSF and blood biomarkers for the diagnosis of Alzheimer's disease: a systematic review and meta-analysis. Lancet Neurol. 2016;15(7):673-84.

28.Hall GF, Saman S. Death or secretion? The demise of a plausible assumption about CSF-tau in Alzheimer Disease? Commun Integr Biol. 2012;5(6):623-6.

29.Pooler AM, Phillips EC, Lau DH, Noble W, Hanger DP. Physiological release of endogenous tau is stimulated by neuronal activity. EMBO Rep. 2013;14(4):389-94.

30. Yamada K, Cirrito JR, Stewart FR, Jiang H, Finn MB, Holmes BB, et al. In vivo microdialysis reveals age-dependent decrease of brain interstitial fluid tau levels in P301S human tau transgenic mice. J Neurosci. 2011;31(37):13110-7.

31.Katsinelos T, Zeitler M, Dimou E, Karakatsani A, Muller HM, Nachman E, et al. Unconventional Secretion Mediates the Trans-cellular Spreading of Tau. Cell Rep. 2018;23(7):2039-55.

32.Iba M, McBride JD, Guo JL, Zhang B, Trojanowski JQ, Lee VM. Tau pathology spread in PS19 tau transgenic mice following locus coeruleus (LC) injections of synthetic tau fibrils is determined by the LC's afferent and efferent connections. Acta Neuropathol. 2015;130(3):349-62.

33. Clavaguera F, Akatsu H, Fraser G, Crowther RA, Frank S, Hench J, et al. Brain homogenates from human tauopathies induce tau inclusions in mouse brain. Proc Natl Acad Sci U S A. 2013;110(23):9535-40.

34.Plouffe V, Mohamed NV, Rivest-McGraw J, Bertrand J, Lauzon M, Leclerc N. Hyperphosphorylation and cleavage at D421 enhance tau secretion. PLoS One. 2012;7(5):e36873.

35.Seppala TT, Koivisto AM, Hartikainen P, Helisalmi S, Soininen H, Herukka SK. Longitudinal changes of CSF biomarkers in Alzheimer's disease. J Alzheimers Dis. 2011;25(4):583-94.

36.Wang Y, Balaji V, Kaniyappan S, Kruger L, Irsen S, Tepper K, et al. The release and transsynaptic transmission of Tau via exosomes. Mol Neurodegener. 2017;12(1):5.

37.Saman S, Kim W, Raya M, Visnick Y, Miro S, Saman S, et al. Exosome-associated tau is secreted in tauopathy models and is selectively phosphorylated in cerebrospinal fluid in early Alzheimer disease. J Biol Chem. 2012;287(6):3842-9.

38.McEwan WA, Falcon B, Vaysburd M, Clift D, Oblak AL, Ghetti B, et al. Cytosolic Fc receptor TRIM21 inhibits seeded tau aggregation. Proc Natl Acad Sci U S A. 2017;114(3):574-9.

39.Agadjanyan MG, Petrovsky N, Ghochikyan A. A fresh perspective from immunologists and vaccine researchers: active vaccination strategies to prevent and reverse Alzheimer's disease. Alzheimers Dement. 2015;11(10):1246-59.

40.Kopke E, Tung YC, Shaikh S, Alonso AC, Iqbal K, Grundke-Iqbal I. Microtubule-associated protein tau. Abnormal phosphorylation of a non-paired helical filament pool in Alzheimer disease. $\mathrm{J}$ Biol Chem. 1993;268(32):24374-84.

41.Hanger DP, Anderton BH, Noble W. Tau phosphorylation: the therapeutic challenge for neurodegenerative disease. Trends Mol Med. 2009;15(3):112-9.

42.Mamun AA, Uddin MS, Mathew B, Ashraf GM. Toxic tau: structural origins of tau aggregation in Alzheimer's disease. Neural Regen Res. 2020;15(8):1417-20.

43.Hamano T, Shirafuji N, Yen SH, Yoshida H, Kanaan NM, Hayashi K, et al. Rho-kinase ROCK inhibitors reduce oligomeric tau protein. Neurobiol Aging. 2020;89:41-54.

44.Arriagada PV, Growdon JH, Hedley-Whyte ET, Hyman BT. Neurofibrillary tangles but not senile plaques parallel duration and severity of Alzheimer's disease. Neurology. 1992;42(3 Pt 1):631-9. 
45.Cho H, Choi JY, Hwang MS, Lee JH, Kim YJ, Lee HM, et al. Tau PET in Alzheimer disease and mild cognitive impairment. Neurology. 2016;87(4):375-83.

46. Ying Z, Wang H, Wang G. The ubiquitin proteasome system as a potential target for the treatment of neurodegenerative diseases. Curr Pharm Des. 2013;19(18):3305-14.

47.van Olst L, Verhaege D, Franssen M, Kamermans A, Roucourt B, Carmans S, et al. Microglial activation arises after aggregation of phosphorylated-tau in a neuron-specific P301S tauopathy mouse model. Neurobiol Aging. 2020;89:89-98.

48.Ittner LM, Ke YD, Delerue F, Bi M, Gladbach A, van Eersel J, et al. Dendritic function of tau mediates amyloid-beta toxicity in Alzheimer's disease mouse models. Cell. 2010;142(3):387-97.

49.Ehehalt R, Keller P, Haass C, Thiele C, Simons K. Amyloidogenic processing of the Alzheimer beta-amyloid precursor protein depends on lipid rafts. J Cell Biol. 2003;160(1):113-23.

50.Ferri CP, Prince M, Brayne C, Brodaty H, Fratiglioni L, Ganguli M, et al. Global prevalence of dementia: a Delphi consensus study. Lancet. 2005;366(9503):2112-7.

51.Khaledi S, Ahmadi S. Amyloid Beta and Tau: from Physiology to Pathology in Alzheimer's disease. Shefaye Khatam. 2016;4(4):67-88.

52.Duyckaerts C, Delatour B, Potier MC. Classification and basic pathology of Alzheimer disease. Acta Neuropathol. 2009;118(1):5-36.

53.Braak H, Braak E, Grundke-Iqbal I, Iqbal K. Occurrence of neuropil threads in the senile human brain and in Alzheimer's disease: a third location of paired helical filaments outside of neurofibrillary tangles and neuritic plaques. Neurosci Lett. 1986;65(3):351-5.

54.Braak E, Braak H, Mandelkow EM. A sequence of cytoskeleton changes related to the formation of neurofibrillary tangles and neuropil threads. Acta Neuropathol. 1994;87(6):554-67.

55.Merino-Serrais P, Benavides-Piccione R, Blazquez-Llorca L, Kastanauskaite A, Rabano A, Avila $\mathrm{J}$, et al. The influence of phospho-tau on dendritic spines of cortical pyramidal neurons in patients with Alzheimer's disease. Brain. 2013;136(Pt 6):1913-28.

56. Yoshida M. Astrocytic inclusions in progressive supranuclear palsy and corticobasal degeneration. Neuropathology. 2014;34(6):555-70.

57.Kovacs GG, Ferrer I, Grinberg LT, Alafuzoff I, Attems J, Budka H, et al. Aging-related tau astrogliopathy (ARTAG): harmonized evaluation strategy. Acta Neuropathol. 2016;131(1):87-102.

58.Braak H, Alafuzoff I, Arzberger T, Kretzschmar H, Del Tredici K. Staging of Alzheimer diseaseassociated neurofibrillary pathology using paraffin sections and immunocytochemistry. Acta Neuropathol. 2006;112(4):389-404.

59. Mesulam M, Shaw P, Mash D, Weintraub S. Cholinergic nucleus basalis tauopathy emerges early in the aging-MCI-AD continuum. Ann Neurol. 2004;55(6):815-28.

60.Crary JF, Trojanowski JQ, Schneider JA, Abisambra JF, Abner EL, Alafuzoff I, et al. Primary agerelated tauopathy (PART): a common pathology associated with human aging. Acta Neuropathol. 2014;128(6):755-66.

61.Duyckaerts C, Bennecib M, Grignon Y, Uchihara T, He Y, Piette F, et al. Modeling the relation between neurofibrillary tangles and intellectual status. Neurobiol Aging. 1997;18(3):267-73.

62.Arendt T. Synaptic plasticity and cell cycle activation in neurons are alternative effector pathways: the 'Dr. Jekyll and Mr. Hyde concept' of Alzheimer's disease or the yin and yang of neuroplasticity. Prog Neurobiol. 2003;71(2-3):83-248.

63.Malia TJ, Teplyakov A, Ernst R, Wu SJ, Lacy ER, Liu X, et al. Epitope mapping and structural basis for the recognition of phosphorylated tau by the anti-tau antibody AT8. Proteins. 2016;84(4):427-34.

64.Bussiere T, Hof PR, Mailliot C, Brown CD, Caillet-Boudin ML, Perl DP, et al. Phosphorylated serine 422 on tau proteins is a pathological epitope found in several diseases with neurofibrillary degeneration. Acta Neuropathol. 1999;97(3):221-30.

65.Luna-Munoz J, Chavez-Macias L, Garcia-Sierra F, Mena R. Earliest stages of tau conformational changes are related to the appearance of a sequence of specific phospho-dependent tau epitopes in Alzheimer's disease. J Alzheimers Dis. 2007;12(4):365-75. 
شهس الدين اaمدى وعا

66.Efthymiou AG, Goate AM. Late onset Alzheimer's disease genetics implicates microglial pathways in disease risk. Mol Neurodegener. 2017;12(1):43.

67.van der Lee SJ, Conway OJ, Jansen I, Carrasquillo MM, Kleineidam L, van den Akker E, et al. A nonsynonymous mutation in PLCG2 reduces the risk of Alzheimer's disease, dementia with Lewy bodies and frontotemporal dementia, and increases the likelihood of longevity. Acta Neuropathol. 2019;138(2):237-50.

68.Keren-Shaul H, Spinrad A, Weiner A, Matcovitch-Natan O, Dvir-Szternfeld R, Ulland TK, et al. A Unique Microglia Type Associated with Restricting Development of Alzheimer's Disease. Cell. 2017;169(7):1276-90.e17.

69.Liu L, MacKenzie KR, Putluri N, Maletić-Savatić M, Bellen HJ. The Glia-Neuron Lactate Shuttle and Elevated ROS Promote Lipid Synthesis in Neurons and Lipid Droplet Accumulation in Glia via APOE/D. Cell Metab. 2017;26(5):719-37.e6.

70.Mauch DH, Nägler K, Schumacher S, Göritz C, Müller EC, Otto A, et al. CNS synaptogenesis promoted by glia-derived cholesterol. Science. 2001;294(5545):1354-7.

71.Yeh FL, Wang Y, Tom I, Gonzalez LC, Sheng M. TREM2 Binds to Apolipoproteins, Including APOE and CLU/APOJ, and Thereby Facilitates Uptake of Amyloid-Beta by Microglia. Neuron. 2016;91(2):328-40.

72.Krasemann S, Madore C, Cialic R, Baufeld C, Calcagno N, El Fatimy R, et al. The TREM2-APOE Pathway Drives the Transcriptional Phenotype of Dysfunctional Microglia in Neurodegenerative Diseases. Immunity. 2017;47(3):566-81.e9.

73.Hansen DV, Hanson JE, Sheng M. Microglia in Alzheimer's disease. J Cell Biol. 2018;217(2):45972.

74.Maphis N, Xu G, Kokiko-Cochran ON, Jiang S, Cardona A, Ransohoff RM, et al. Reactive microglia drive tau pathology and contribute to the spreading of pathological tau in the brain. Brain. 2015;138(Pt 6):1738-55.

75.Bhaskar K, Konerth M, Kokiko-Cochran ON, Cardona A, Ransohoff RM, Lamb BT. Regulation of tau pathology by the microglial fractalkine receptor. Neuron. 2010;68(1):19-31.

76. Meda L, Cassatella MA, Szendrei GI, Otvos L, Jr., Baron P, Villalba M, et al. Activation of microglial cells by beta-amyloid protein and interferon-gamma. Nature. 1995;374(6523):647-50.

77.Lin YT, Seo J, Gao F, Feldman HM, Wen HL, Penney J, et al. APOE4 Causes Widespread Molecular and Cellular Alterations Associated with Alzheimer's Disease Phenotypes in Human iPSCDerived Brain Cell Types. Neuron. 2018;98(6):1141-54.e7.

78.Ahmadi S, Zobeiri M, Bradburn S. Molecular mechanisms underlying actions of certain long noncoding RNAs in Alzheimer's disease. Metab Brain Dis. 2020;35(5):681-93.

79.Khaledi S, Ahmadi S. Cellular and molecular mechanisms of vitamin D deficiency in aging and Alzheimer's disease. Shefaye Khatam. 2020; In Press.

80.Rebeiz JJ, Kolodny EH, Richardson EP, Jr. Corticodentatonigral degeneration with neuronal achromasia. Arch Neurol. 1968;18(1):20-33.

81.Gibb WR, Luthert PJ, Marsden CD. Corticobasal degeneration. Brain. 1989;112 ( Pt 5):1171-92.

82.Kouri N, Whitwell JL, Josephs KA, Rademakers R, Dickson DW. Corticobasal degeneration: a pathologically distinct 4R tauopathy. Nat Rev Neurol. 2011;7(5):263-72.

83.Corticobasal Degegeneration: Essential facts for pateints. https://www.movementdisorders.org/MDS.../pat-Handouts-CBD-v1.pdf.

84.Armstrong MJ, Litvan I, Lang AE, Bak TH, Bhatia KP, Borroni B, et al. Criteria for the diagnosis of corticobasal degeneration. Neurology. 2013;80(5):496-503.

85.Morris HR, Lees AJ, Wood NW. Neurofibrillary tangle parkinsonian disorders--tau pathology and tau genetics. Mov Disord. 1999;14(5):731-6.

86.Dickson DW, Liu WK, Ksiezak-Reding H, Yen SH. Neuropathologic and molecular considerations. Adv Neurol. 2000;82:9-27.

87.Di Maria E, Tabaton M, Vigo T, Abbruzzese G, Bellone E, Donati C, et al. Corticobasal degeneration shares a common genetic background with progressive supranuclear palsy. Ann Neurol. 2000;47(3):374-7. 
88.Houlden H, Baker M, Morris HR, MacDonald N, Pickering-Brown S, Adamson J, et al. Corticobasal degeneration and progressive supranuclear palsy share a common tau haplotype. Neurology. 2001;56(12):1702-6.

89.Steele JC, Richardson JC, Olszewski J. Progressive Supranuclear Palsy. A heterogeneous degeneration involving the brain stem, basal ganglia and cerebellum with vertical gaze and pseudobulbar palsy, nuchal dystonia and dementia. Arch Neurol. 1964;10:333-59.

90.Kawashima M, Miyake M, Kusumi M, Adachi Y, Nakashima K. Prevalence of progressive supranuclear palsy in Yonago, Japan. Mov Disord. 2004;19(10):1239-40.

91.Golbe LI. Progressive supranuclear palsy. Semin Neurol. 2014;34(2):151-9.

92.Progressive Supranuclear Palsy: Essential facts for pateins: https://www.movementdisorders.org/...PSP/pat-Handouts-PSP-v5.pdf.

93.Jabbari E, Holland N, Chelban V, Jones PS, Lamb R, Rawlinson C, et al. Diagnosis Across the Spectrum of Progressive Supranuclear Palsy and Corticobasal Syndrome. JAMA Neurol. 2020;77(3):377-87.

94.Baron JC, Maziere B, Loc'h C, Sgouropoulos P, Bonnet AM, Agid Y. Progressive supranuclear palsy: loss of striatal dopamine receptors demonstrated in vivo by positron tomography. Lancet. 1985;1(8438):1163-4.

95.Pollock NJ, Mirra SS, Binder LI, Hansen LA, Wood JG. Filamentous aggregates in Pick's disease, progressive supranuclear palsy, and Alzheimer's disease share antigenic determinants with microtubule-associated protein, tau. Lancet. 1986;2(8517):1211.

96.Schoch KM, DeVos SL, Miller RL, Chun SJ, Norrbom M, Wozniak DF, et al. Increased 4R-Tau Induces Pathological Changes in a Human-Tau Mouse Model. Neuron. 2016;90(5):941-7.

97.Noble W, Planel E, Zehr C, Olm V, Meyerson J, Suleman F, et al. Inhibition of glycogen synthase kinase- 3 by lithium correlates with reduced tauopathy and degeneration in vivo. Proc Natl Acad Sci U S A. 2005;102(19):6990-5.

98.Coughlin DG, Litvan I. Progressive supranuclear palsy: Advances in diagnosis and management. Parkinsonism Relat Disord. 2020;73:105-16.

99.Höglinger GU, Respondek G, Stamelou M, Kurz C, Josephs KA, Lang AE, et al. Clinical diagnosis of progressive supranuclear palsy: The movement disorder society criteria. Mov Disord. 2017;32(6):853-64.

100.Respondek G, Kurz C, Arzberger T, Compta Y, Englund E, Ferguson LW, et al. Which ante mortem clinical features predict progressive supranuclear palsy pathology? Mov Disord. 2017;32(7):995-1005. 